\title{
Review
}

\section{Signaling and regulation of G protein-coupled receptors in airway smooth muscle}

\author{
Charlotte K Billington and Raymond B Penn*
}

Department of Medicine, Division of Critical Care, Pulmonary, Allergic \& Immunologic Diseases, and Kimmel Cancer Center, Jefferson Medical College, Thomas Jefferson University, Philadelphia, PA 19107

Correspondence: Raymond B Penn - ray.penn@mail.tju.edu

Respir Res 2003, 4:2

Revisions requested: 07 October 2002

Revisions received: 09 October 2002

Accepted: 14 October 2002

2003 Billington et al., licensee BioMed Central Ltd

Published: 14 March 2003

(Print ISSN 1465-9921; Online ISSN 1465-993X)

\begin{abstract}
Signaling through G protein-coupled receptors (GPCRs) mediates numerous airway smooth muscle (ASM) functions including contraction, growth, and "synthetic" functions that orchestrate airway inflammation and promote remodeling of airway architecture. In this review we provide a comprehensive overview of the GPCRs that have been identified in ASM cells, and discuss the extent to which signaling via these GPCRs has been characterized and linked to distinct ASM functions. In addition, we examine the role of GPCR signaling and its regulation in asthma and asthma treatment, and suggest an integrative model whereby an imbalance of GPCR-derived signals in ASM cells contributes to the asthmatic state.
\end{abstract}

Keywords: G protein-coupled receptor, airway smooth muscle, inflammation, synthetic function, airway remodeling

\section{Introduction}

G protein coupled receptors (GPCRs) comprise a superfamily of proteins capable of transducing a wide range of extracellular signals across the plasma membrane of the cell into discrete intracellular messages capable of regulating numerous, diverse cell functions. Over 800 GPCRs have been cloned to date and over 1000 are suspected in the human genome [1]. The majority of all prescribed drugs target either activation of GPCRs or their downstream signals. This holds true for drugs used in the management of airway diseases such as asthma; it is generally accepted that GPCRs on airway smooth muscle (ASM) are the direct targets of the majority of anti-asthma drugs.

Until recently most research efforts examining GPCR expression, function, and regulation in ASM have focused on those receptors capable of dynamic regulation of ASM contractile state and consequently, airway resistance. However, the growing appreciation of ASM as a pleiotropic cell capable of regulating airway resistance via "synthetic functions" has provided a much wider context in which to consider the relevance of numerous ASM GPCRs. GPCRs whose activation has little or no direct impact on contractile state may instead modulate ASM growth or the secretion of various cytokines, chemokines, eicosanoids, or growth factors that orchestrate airway inflammation through actions on both mesenchymal and infiltrating cells. These effects may ultimately influence airway resistance by: 1) promoting airway remodeling that impacts the mechanics of ASM contraction in vivo; or 2) regulating the inflammatory response to either disrupt the balance of local pro-contractile/relaxant molecules or alter electro- or pharmaco-mechanical coupling in ASM. Accordingly, it is no longer permissible to judge the relevance of a given ASM GPCR based on its ability to dynamically modulate ASM contractile state and airway resistance. Indeed, our newfound appreciation of multiple experimental endpoints defining ASM function has aided efforts to identify relevant ASM GPCRs and their signaling properties.

In this review we will summarize the signaling and functional effects of various GPCRs that have been identified in ASM cells. In addition, we will consider how the regulation 
(or dysregulation) of GPCR signaling potentially impacts asthma pathogenesis and treatment.

\section{Models for analyzing GPCR signaling in ASM}

Models for analyzing GPCR signaling in ASM run the spectrum of integrative to reductionist approaches, each having certain advantages and disadvantages. Integrative in vivo models in which GPCR ligands are administered systemically or through inhalation can suggest the presence of ASM GPCRs capable of mediating bronchoconstrictive or relaxant effects. Such experiments can provide important insight into the role of a given GPCR in regulating lung resistance, and suggest the utility of targeting a receptor in order to control bronchospasm. However, the direct target cell of delivered agents is often unclear, and frequently the response of ASM is secondary to actions on other cell types. For example, inhaled agents can provoke the release of bronchoreactive substances from multiple cell types that in turn engage ASM GPCRs, or regulate autonomic control of ASM contraction through actions on pre- or post-ganglionic neurons or reflex arcs [2-4].

A more controlled environment in which to characterize ASM GPCRs is provided by ex vivo analyses of tracheal or bronchial smooth muscle isolated as strips or as part of a complex including cartilaginous ring. This approach reduces, but does not eliminate, neural or paracrine effects on ASM that can dominate functional ASM responses in vivo. Such effects can persist because preparations still include autonomic effector and sensory nerve fiber endings, epithelium, fibroblasts, and blood cells capable of releasing constricting/relaxing agents in response to exogenous agents or, possibly, mechanical forces [5]. Consequently, intelligent design of such ex vivo analyses can help clarify the in vivo effects of numerous agents and identify their target cells. For example, immunohistochemical analysis and tissue bath mechanics of excised ASM strips suggest that the pronounced bronchoconstriction elicited by inhaled adenosine or adenosine monophosphate in asthmatic subjects or sensitized animals can be attributed primarily to histamine release from mast cells in close proximity to or imbedded in ASM tissue [6-11].

Arguably, the development of ASM cell cultures has provided the most reliable system for identifying and characterizing ASM GPCRs. Typically generated by enzymatic dissociation of ASM cells from sections of tracheae or bronchi, ASM cultures provide a pure population of ASM cells that can be greatly expanded, and thus are amenable to extensive pharmacological, biochemical, and molecular analyses not possible in vivo or with tissues [12,13]. Cells of ASM cultures of several species (including human, canine, bovine, guinea pig, and mouse) have been shown to be morphologically and functionally similar to ASM in vivo; they stain for smooth muscle-alpha-actin and myosin heavy chain, and exhibit signaling and functional responses that are consistent with ASM function observed or suspected in vivo [12-15].

The power of ASM cultures as an experimental model capable of verifying existing and identifying new signaling paradigms, while also establishing their physiologic relevance, is under-appreciated. This power is largely attributed to the fact that ASM cells possess physiologic levels of most signaling components (e.g., receptors, effectors, and downstream signaling intermediates), yet many signaling pathways are readily characterized with robust signal to noise ratios. Most importantly, numerous ASM cell functions (including growth, synthesis/secretion of autocrine/ paracrine factors, and to a limited extent, contraction) are also easily quantified and can be linked to their associated signaling events. In many other cell culture systems such linkage of signaling to relevant cell function cannot be achieved. For example, the majority of studies revealing novel receptor-mediated signaling paradigms have utilized expression systems such as COS or HEK293 cells to express recombinant receptors or signaling components in order to delineate pathway interactions and their modes of regulation. It is unclear whether such paradigms occur under relevant conditions in which most signaling components are expressed at low levels and their actions may be constrained by compartmentalization $[16,17]$. Moreover, whether such signaling has any relevance to cell function is unclear, because such cells typically either lack discrete measurable functions or their functions are known to be dysregulated (e.g., physiologic regulation of growth cannot be studied in a transformed cell). Recent studies [18-20] have begun testing the applicability and physiologic relevance of various GPCR signaling paradigms in cultured ASM cells.

However, ASM cultures as a model system are far from perfect. That ASM cells in culture lack the context of the in vivo condition is not only a strength but also an inherent limitation of this reductionist model. Moreover, like most primary cells grown in culture, ASM cells undergo a degree of dedifferentiation that coincides with a loss or increase in various signaling elements and functional apparatus [3]. Specific changes in ASM cells relevant to GPCR signaling that are known to occur in culture include a rapid and progressive decrease in the expression of $\mathrm{Gq}$-coupled receptors such as the $\mathrm{m} 3$ muscarinic acetylcholine receptor (m3 $\mathrm{mAChR}$ [21] and the cysteinyl leukotriene type 1 receptor (CLT1R; Stuart Hirst, personal communication). In addition, contractile function of cultured ASM cells is rapidly diminished, coinciding with reduced expression of smooth muscle alpha-actin and myosin heavy chain, calponin, hcaldesmon, beta-tropomyosin, and myosin light chain kinase (MLCK) [22]. However, Shore, Fredberg, and colleagues have developed a model for examining agonist- 
induced changes in stiffness of cultured ASM cells that has provided useful information linking regulation of GPCR signaling with ASM contractile state [23]. Interestingly, Stephens [24], Halayko, Solway [25-27], and colleagues have demonstrated that prolonged serum starvation of cultured canine ASM cells can beget a subpopulation of cells that reacquire high $\mathrm{m} 3 \mathrm{mAChR}$ and contractile/cytoskeletal protein expression and thus contractile function. These findings suggest a potentially powerful strategy for delineating elements critical to Gq-coupled receptor signaling and pharmaco-mechanical coupling in ASM.

\section{Gq-coupled receptors}

Although numerous GPCRs have the ability to couple to more than one heterotrimeric G protein, a given GPCR is typically classified based on the $G$ protein subfamily (e.g., $\mathrm{Gs}, \mathrm{Gi} / \mathrm{o}$, or $\mathrm{Gq} / 11$ ) it preferentially activates. A diagram of Gq-coupled receptor signaling, and the associated functional outcomes in ASM, is provided in Fig. 1. Signaling via Gq-coupled receptors in ASM is of particular interest due to its prominent role in promoting ASM contraction. Transmembrane signaling occurs in the classical GPCR-G protein-effector protein paradigm. An agonist-bound receptor undergoes a conformational change that promotes its association with and activation of the heterotrimeric $G$ protein $\mathrm{Gq}$. The extreme $\mathrm{C}$-terminus of the $\mathrm{G}$ alpha subunit is the receptor recognition domain and dictates receptor-G $\alpha$ specificity. Receptor-G $\alpha$ association promotes the release of GDP from $\mathrm{G} \alpha$ and binding of GTP. The active GTPbound $G \alpha$ dissociates from $G \beta \gamma$ and in turn activates an effector molecule. The G $\beta \gamma$ heterodimer (numerous combinations of 7 different $\beta$ and 12 different $\gamma$ subunits exist) also has the capacity to regulate the activity of various effectors and numerous other signaling elements (discussed below). The duration of one cycle of receptor activation of effector is dictated by the GTPase activity of $\mathrm{G} \alpha$, as the hydrolysis of GTP to GDP promotes reconstitution and membrane localization of the $G \alpha \beta \gamma$ trimer. Traditionally, alpha subunit GTPase activity was presumed "intrinsic", but it is now appreciated that this activity can be regulated by GTPase proteins (GAPs) in a manner similar to that demonstrated for small G proteins [28]. Phospholipase C (PLC) is the principal effector of Gq-mediated signaling. Eleven different isoforms of PLC exist and exhibit distinct patterns of regulation; members of the PLC $\beta$ subfamily tend to mediate the actions of activated $\mathrm{Gq}$ [29]. Activated PLC hydrolyzes phosphoinositol 4,5-bisphosphate $\left(\mathrm{PIP}_{2}\right)$ into 1,2-diacylglycerol (DAG) and inositol 1,4,5-trisphosphate $\left(\mathrm{IP}_{3}\right)$. The net effect of increased $\mathrm{IP}_{3}$ and DAG levels is to increase intracellular $\mathrm{Ca}^{2+}$ through release from internal stores and influx from membrane-bound channels [3], and in ASM to activate the cell's contractile machinery through both $\mathrm{Ca}^{2+}$ and protein kinase $\mathrm{C}$ (PKC) -dependent mechanisms [3033] (see Fig. 1 Legend for details).
Studies of agonist-induced increases in airway resistance, smooth muscle contraction ex vivo, and receptor binding and second messenger analyses of cultured ASM cells have helped identify numerous Gq-coupled receptors in ASM (Table 1). Resting ASM tone in vivo is determined primarily by parasympathetic cholinergic innervation acting on ASM m3 mAChRs. Other ASM Gq-coupled receptors capable of inducing significant ASM contraction (in vivo or ex vivo) include the $\mathrm{H} 1$ histamine receptor, CLT1R, B2 bradykinin receptors, and ET-A endothelin receptor. Additional Gq-coupled receptors such as the A3 adenosine, NK-1, NK-2 (Neurokinin-1 and -2) and P2 purinergic have been identified, but their importance in mediating contraction under physiologic or pathologic conditions is unclear. In some cases the evidence for their expression in ASM is either indirect or is difficult to interpret given the labile nature of Gqcoupled receptor expression in ASM cultures.

However, as noted above ASM cells do more than contract and studies of other functional outcomes in ASM suggest a potentially important role for numerous Gq-coupled receptors in modulating ASM synthetic functions. Both thrombin (capable of activating Gq through protease-activated receptors (PARs) [34]) and lysophosphatidic acid (LPA) (capable of activating Gq through endothelium differentiation gene (EDG) receptors) are strong stimulators of cultured ASM DNA synthesis and cell proliferation. These effects appear in part Gq-dependent (Billington and Penn, unpublished observations) and may be mediated by the capacity of $\mathrm{Gq}$ signaling to stimulate the p42/p44 MAPK (via PKC-mediated phosphorylation of Raf-1) and p70S6K pathways and therefore induce promitogenic transcription factor activation, cyclin D1 induction, and upregulate the translational machinery necessary for cell cycle progression [36,37]. Moreover, numerous Gq-coupled receptor agonists including thrombin, lysophosphatidic acid, leukotriene D4 (LTD4), endothelin, histamine, thromboxane (activating Thromboxane A2 / Prostaglandin (TP) receptors)[19], and sphingosine-1-phosphate (SPP) (activating EDG receptors) have been shown to potentiate the mitogenic effects of receptor tyrosine kinase signaling, although it has not been established that $\mathrm{Gq}$ activation per se mediates this effect.

Gq-dependent activation of PKC and p42/p44 also promotes phosphorylation and activation of phospholipase A2 (PLA2), which contributes to rapid eicosanoid synthesis in ASM cells stimulated with bradykinin (acting on B2 bradykinin receptors) [39]. Other effects reported to involve $\mathrm{Gq}$ activation by ASM GPCRs include actin polymerization induced by LPA, endothelin, or carbachol, which appears to occur via a Rho-dependent mechanism [40]. This suggests that effectors other than PLC can be directly activated by Gq in ASM. 
Respiratory Research Vol 4 No 1 Billington et al.

Figure 1

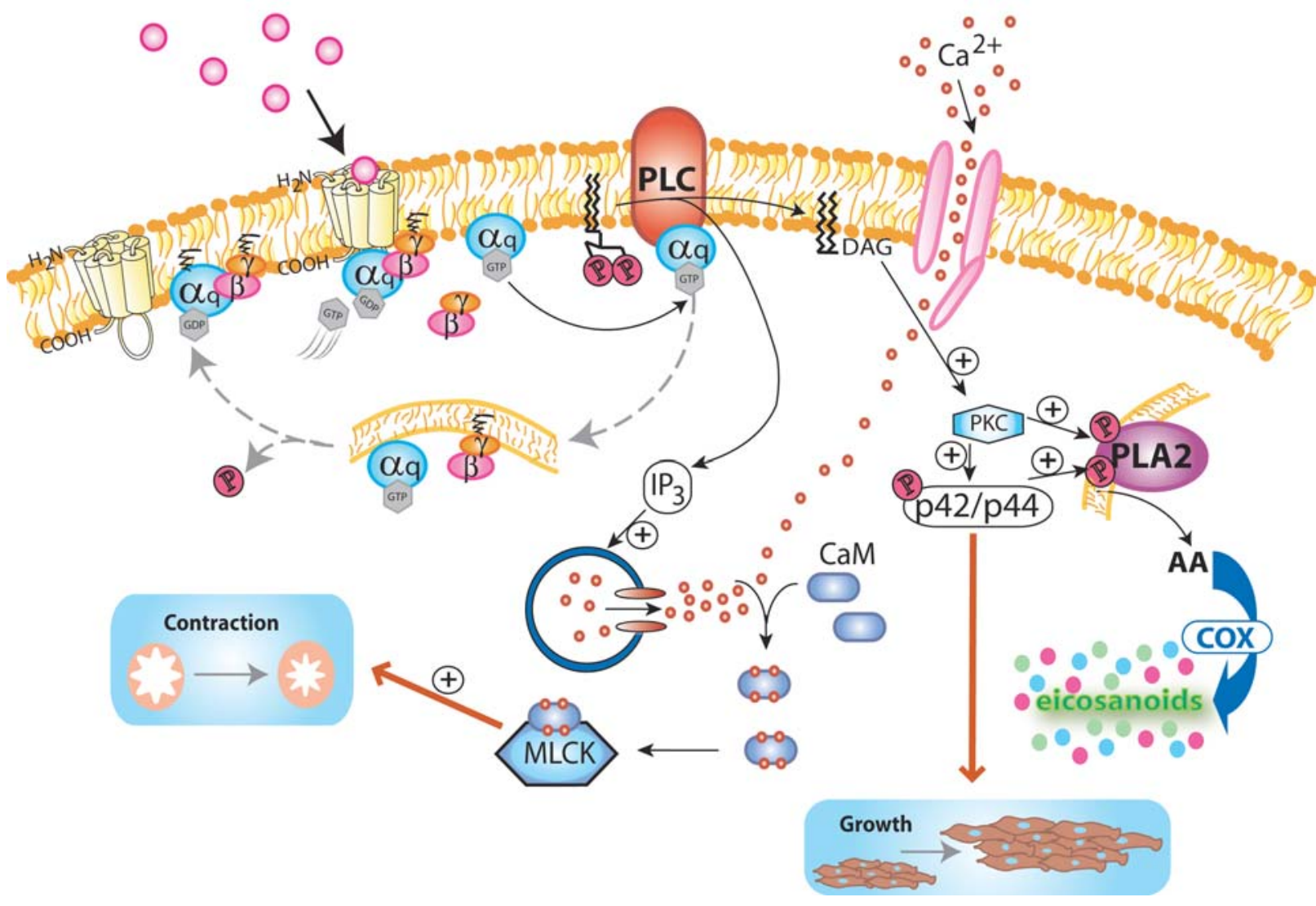

Gq-coupled receptor signaling in airway smooth muscle. Airway smooth muscle (ASM) is innervated by postganglionic parasympathetic nerves that release acetylcholine (acting on $\mathrm{m} 3 \mathrm{mAChRs}$ ) to control resting ASM tone. In addition to the $\mathrm{m} 3$ muscarinic acetylcholine receptor (mAChR), other Gq-coupled coupled receptors are expressed in ASM (see Table 1), and can similarly mediate contraction and other depicted ASM functions. Transmembrane signaling of G protein-coupled receptors (GPCRs) involves sequential activation of receptor, G protein, and effector. Upon agonist binding, the receptor undergoes a conformational change exposing a high-affinity binding site for a G-protein in its GDP-bound inactive state. The receptor specifically interacts with the $\mathrm{C}$-terminus of the $\alpha$ subunit of the $\mathrm{G}$-protein heterotrimer. G-protein binding to receptor releases the nucleotide leaving an empty nucleotide binding pocket readily occupied by GTP, which exists at a higher cytosolic concentration than GDP. This exchange of the G-protein-bound GDP for GTP induces a conformational change in the switch region of G $\alpha$ and causes the dissociation of G $\alpha$ from the $G \beta \gamma$ dimer. The $G \beta$ and $G \gamma$ subunits are tightly associated and remain anchored into the lipid bilayer due to the prenylation of the $G \gamma$ subunit $-a$

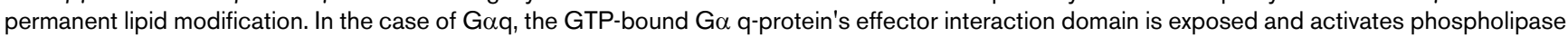
C (PLC). PLC promotes the hydrolysis of phosphoinositol 4,5-bisphosphate (PIP2) into the intracellular messengers 1,2-diacylglycerol (DAG) and inositol 1,4,5-trisphosphate $\left(\mathrm{IP}_{3}\right)$. DAG remains membrane bound and promotes the translocation of protein kinase $\mathrm{C}$ (PKC) from the cytoplasm to the membrane and its subsequent activation. Activated PKC is capable of phosphorylating a number of substrates including calponin; PKC-mediated phosphorylation of calponin results in a loss of calponin's ability to inhibit actomyosin ATPase [30,269]. PKC also phosphorylates intermediates of MAPK signaling pathways, which activate various gene transcription factors involved in promoting ASM growth. Gq-coupled receptors are also able to impact receptor tyrosine kinase-induced ASM growth via a synergistic activation of p70S6K. Both PKC and p42/p44 MAPK phosphorylate and stimulate the catalytic activity of phospholipase A2 (PLA2). Calcium binding to PLA2 triggers its association with the plasma or nuclear membrane and the subsequent cleaving and release of arachadonic acid (AA). The conversion of AA to prostaglandins and thromboxanes is facilitated by cyclo-oxygenase-2, a highly regulated enzyme upregulated by pro-inflammatory agents including lipopolysaccharide, cytokines and growth factors. The other product of $\mathrm{PIP}_{2}$ hydrolysis, $\mathrm{IP}_{3}$, translocates and binds to $\mathrm{IP}_{3}$ receptors located on sarcoplasmic calcium stores. Activation of $\mathrm{IP}_{3}$ receptors results in the opening of $\mathrm{Ca}^{2+}$ channels and calcium efflux into the cytosol. Intracellular calcium stores are the major source of elevated calcium mediating ASM contraction, although influx from receptor-operated calcium channels can contribute. The rise in intracellular calcium promotes calcium binding to calmodulin forming calcium-calmodulin complexes that activate myosin light chain kinase (MLCK). MLCK phosphorylates myosin light chains and enables actin to activate the myosin ATPase activity required for cross-bridge cycling and contraction. Via its interaction with various guanine-nucleotide exchange factors for Rho (RhoGEFs), Gq has also recently been shown to activate the small G protein Rho [270]. In ASM, Gqmediated activation of Rho has been implicated in regulating actin cytoskeletal rearrangement [40]. Rho is also a key mediator of calcium sensitization - a phenomenon observed following stimulation with numerous GPCRs whereby heightened contractile effects can be induced for a given level of calcium mobilization. Rho activates Rho kinase, which in turn phosphorylates the myosin binding subunit of myosin light chain phosphatase (MLCP) to inhibit phosphatase activity, resulting in net increased phosphorylation of myosin light chain (MLC) and an associated increase in crossbridge cycling [271]. Although activation of $\mathrm{G}_{12 / 13}$ is most commonly associated with Rho activity, studies of ASM suggest that $\mathrm{Gq}$ and $\mathrm{Gi}$ can also participate in Rho-mediated functions $[40,272,273]$. 


\begin{tabular}{|c|c|c|c|c|}
\hline GPCR & References & Couples to & Functions in $\mathrm{ASM}^{1}$ & Comment \\
\hline 5-HT & {$[125,126,213-215]$} & $\mathrm{Gi}^{2}$ & CXN, GP & 5-HT2c identified, other subtypes likely \\
\hline A1 adenosine & {$[42,216,217]$} & Gi & CXN & Low levels suggested in human ASM \\
\hline $\mathrm{A} 2 \mathrm{~b}$ adenosine & {$[42]$} & $\mathrm{Gs}^{3}$ & RLXN & $\begin{array}{c}\text { Mediates effects of autocrine and paracrine } \\
\text { adenosine }\end{array}$ \\
\hline A3 adenosine & {$[218,219]$} & $\mathrm{Gq}^{4}$ & unclear & \\
\hline$\alpha-1$ adrenergic & [220-223] & $\mathrm{Gq}$ & unclear & $\begin{array}{c}\text { Only response in lung or ex vivo occurs with } \\
\beta A R \text { antagonist present }\end{array}$ \\
\hline$\beta_{2}$ adrenergic & {$[56,185,224,225]$} & Gs & RLXN, Cyt, Gl & \\
\hline BK bradykinin & {$[39,226-231]$} & $\mathrm{Gq}$ & CXN & $\begin{array}{l}\text { Robust activation of PLC and PLA2 in cul- } \\
\text { tured ASM;putative B3 yet to be cloned }\end{array}$ \\
\hline CLT1R & {$[232-236]$} & $\mathrm{Gq}$ & CXN, GP & $\begin{array}{l}\text { CLT1R antagonists most therapeutic of all } \\
\text { GqCR antagonists }\end{array}$ \\
\hline ET-A/B & [237-242] & $\mathrm{Gq}$ & CXN, GP & \\
\hline EDG $1-7$ & {$[38,243-245]$} & $\mathrm{Gq}, \mathrm{Gi}, \mathrm{G}_{12 / 13}$ & GS, Cyt & $\begin{array}{c}\text { Most subtypes exhibit promiscuity toward G } \\
\text { proteins }\end{array}$ \\
\hline EP2 & {$[20,246,247]$} & Gs & RLXN, Gl, Cyt & $\begin{array}{l}\text { Indirect evidence for expression of EP1, } \\
\text { EP3, and EP4 }\end{array}$ \\
\hline $\mathrm{H} 1$ histamine & {$[248,249]$} & Gq & CXN, GP & $\begin{array}{c}\text { Exhibits homologous and heterologous } \\
\text { desensitization }\end{array}$ \\
\hline IP Prostacyclin & {$[41,250]$} & Gs & Gl & $\begin{array}{l}\text { Responsive to autocrine PGI2 induced by } \\
\text { cytokines via COX-2 induction }\end{array}$ \\
\hline m2 muscarinic & {$[21,251,252]$} & Gi & unclear & $\begin{array}{l}\text { Mediator of acute adenylyl cyclase inhibi- } \\
\text { tion, chronic sensitization }\end{array}$ \\
\hline $\mathrm{m} 3$ muscarinic & {$[251-256]$} & $\mathrm{Gq}$ & CXN, GP & Rapid reduction of expression in culture \\
\hline NK-1/2 & [257-260] & $\mathrm{Gq}$ & CXN, GP & \\
\hline PAR-1,2,3 & {$[34,261,262]$} & $\mathrm{Gq}, \mathrm{Gi}, \mathrm{G}_{12 / 13}$ & GS, GP & $\begin{array}{l}\text { Thrombin most mitogenic GPCR agonist; } \\
\text { subtype promiscuity towards G proteins }\end{array}$ \\
\hline P2 purinergic & {$[218,219]$} & $\mathrm{Gq}$ & unclear & P1 may also be expressed \\
\hline TP & {$[41,263-266]$} & $\mathrm{Gq}, \mathrm{Gi}, \mathrm{G}_{12 / 13}(?)$ & CXN, GP & $\begin{array}{l}\text { Coupling specificity poorly characterized in } \\
\text { ASM }\end{array}$ \\
\hline VIP & {$[43,267,268]$} & Gs & Gl & \\
\hline
\end{tabular}

1 Abbreviations: CXN - contraction; Cyt - regulation of ASM cytokine/chemokine synthesis; Gl-inhibition of ASM growth (DNA synthesis/cell proliferation); GP - potentiation of growth stimulated by polypeptide growth factors; GS - growth stimulation ; RLXN - relaxation 2 Coupling to Gi is suggested by sensitivity of signal transduction or functional effects to pertussis toxin ${ }^{3}$ All receptors noted to couple to Gs have been shown to stimulate cAMP production in ASM. ${ }^{4}$ Coupling of receptors to Gq is suggested by either agonist-stimulated phosphoinositide production or calcium flux.

\section{Gs-coupled receptors}

Whereas Gq-coupled receptors are the principal mediators of ASM contraction, Gs-coupled receptors on ASM play a central role in promoting relaxation of contracted ASM and in conferring prophylactic "bronchoprotection". Inhaled beta-agonists, which activate the Gs-coupled beta2-adrenergic receptor ( $\left.\beta_{2} A R\right)$ on $A S M$, are the most widely used agents in asthma therapy and are universally recognized as the treatment of choice for acute asthma attacks. Several other Gs-coupled receptors, including the E-Prostanoid 2 (EP2) prostaglandin E2 $\left(\mathrm{PGE}_{2}\right)$ [20], IP prostacyclin ([41] and Pascual and Penn, unpublished observations), A2b adenosine [42], and vasoactive intestinal peptide (VIP)[43] receptors have been identified in ASM and represent intriguing, albeit elusive, therapeutic targets (Table 1 ).

Gs-coupled receptor signaling and its regulation have been extensively characterized in numerous cells types, including ASM [44]. The overwhelming majority of studies delineating the basic tenets of Gs-coupled receptor signaling have examined $\beta_{2} A R$ signaling, based on the prevalence of endogenously expressed $\beta_{2} A R s$, the established relevance of $\beta_{2} A R s$ in the function of several organ systems, the existence of highly selective $\beta_{2} A R$ ligands, and the early cloning of the $\beta_{2} A R$ enabling heterologous expression of the receptor in various cell systems. Figure 2 depicts the most prominent features of Gs-coupled receptor signaling and functional consequences in ASM cells.

Adenylyl cyclase (AC) is the principal effector of Gs-coupled receptor transmembrane signaling. Nine isoforms (type I through IX) of AC are known to exist [45]. RT-PCR has identified transcripts of all AC subtypes except III and VIII in human ASM cultures, although immunoblot analysis suggests the presence of only V/VI (existing antibodies do not distinguish between type $\mathrm{V}$ and $\mathrm{VI}$ ), and analyses of $\mathrm{AC}$ regulation in human $A S M$ cultures (discussed below) are consistent with the expression of $A C V$ and VI $[46,47]$. Interestingly, AC subtype expression in ASM cultures may be 
Respiratory Research Vol 4 No 1 Billington et al.

Figure 2

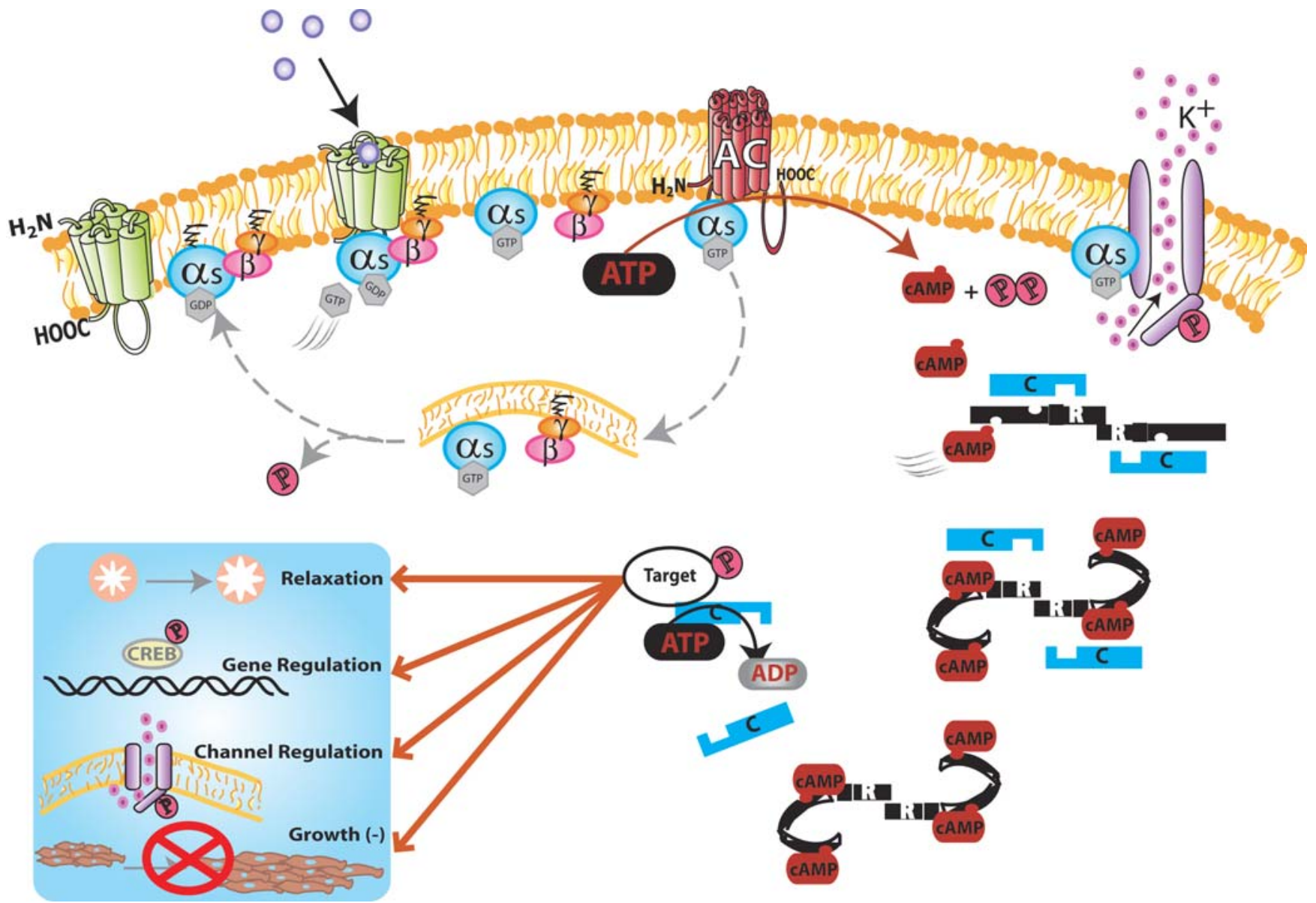

Gs-coupled receptor signaling in airway smooth muscle. Gs-coupled receptors on airway smooth muscle (ASM) are activated by endogenous agents such as circulating catecholamines, prostaglandins and iso-prostanes, adenosine and vasoactive intestinal peptide (VIP). Activated G $\alpha$ s binds to and activates membrane bound adenylyl cyclase (AC). AC is comprised of eight membrane-spanning $\alpha$-helices, and two cytosolic domains which are required for catalytic activity and integrate various regulatory signals. The cytosolic domains possess specific binding sites for the G-protein subunits $\mathrm{G} \alpha$, G $\alpha$ i, and $\mathrm{G} \beta \gamma$. Of the nine know AC isoforms, AC V and VI appear be expressed and functionally important in human ASM. Adenylyl cyclase activation catalyzes the formation of cyclic AMP from cytoplasmic ATP. Cyclic AMP is a ubiquitous second messenger whose principal function is to activate protein kinase A (PKA). Inactive PKA exists as a complex comprising two regulatory and two catalytic subunits. The high affinity binding of cyclic AMP to domains in the regulatory region induces a conformational change forcing the release of the active catalytic subunits. PKAmediated phosphorylation of various intracellular proteins has widespread effects in ASM. PKA can phosphorylate certain Gq-coupled receptors as well as phospholipase C (PLC) and thereby inhibit G protein-coupled receptor (GPCR) -PLC-mediated phosphoinositide (PI) generation, and thus calcium flux. PKA phosphorylates the inositol 1,4,5-trisphosphate $\left(\mathrm{IP}_{3}\right)$ receptor to reduce its affinity for $\mathrm{IP}_{3}$ and further limit calcium mobilization. PKA phosphorylates myosin light chain kinase (MLCK) and decreases its affinity to calcium calmodulin, thus reducing activity and myosin light chain (MLC) phosphorylation. PKA also phosphorylates $\mathrm{K}_{\mathrm{Ca++}}$ channels in ASM, increasing their open-state probability (and therefore $\mathrm{K}+$ efflux) and promoting hyperpolarization. Through its phosphorylation of the transcription factor CREB and its (typically inhibitory) effects on GPCR and receptor tyrosine kinase signaling, PKA regulates the transcription of numerous genes. Recent studies suggest that cAMP/PKA mediates regulation of the expression of numerous immunomodulatory proteins in ASM including IL-6, RANTES, eotaxin, and GM-CSF [53,54,274-276]. Although poorly characterized, the growth inhibitory effect of Gs-coupled receptor activation in ASM is consistent with the known effects of PKA on mitogenic signaling. These effects include inhibition of p42/p44 MAPK signaling via phosphorylation and inhibition of the upstream intermediate raf-1, and via inhibition of promitogenic transcriptional regulation mediated by phospho-CREB. Lastly, Gs-coupled receptor activation is also believed to promote PKA-independent effects, including gating of $\mathrm{K}_{\mathrm{Ca}++}$ channels directly by $\mathrm{G} \alpha \mathrm{s}$ [56], and actin polymerization via an unestablished mechanism [55].

species specific, as regulatory features of $\mathrm{AC}$ in bovine, canine, and guinea pig ASM suggest prominent expression of AC II [48-51], whereas a minimal [46] or no [47] level of AC II transcripts were detected in human ASM (see below).
Adenylyl cyclase isoforms are subject to multiple forms of regulation (discussed below), although dynamic activation of $A C$ under physiologic conditions occurs almost exclusively by interaction with Gas [52]. Gas activation of AC 
catalyzes ATP to cyclic AMP (cAMP), which in turn binds to the regulatory subunits of the cAMP-dependent protein kinase (protein kinase A or PKA). The cAMP-bound regulatory subunits then dissociate from and thereby activate the catalytic subunits of the enzyme, which in turn phosphorylate and regulate the activity of numerous proteins, including the transcription factor CREB. PKA activity is presumed responsible for the majority of cellular actions elicited by Gs-coupled receptor activation, which in ASM include relaxation, altered transcription of numerous genes that impact airway inflammation and remodeling [53,54], inhibition of cell growth, and ion channel gating [3]. However, cAMP/PKA -independent signaling by Gs-coupled receptors has also been proposed and may have important functional consequences in ASM. These include beta-agonistinduced actin depolymerization [55], direct activation of $\mathrm{Ca}^{2+}$-sensitive $\mathrm{K}^{+}$channels by $\mathrm{G} \alpha$ s subunits [56], and possibly other ill-defined signaling events that promote relaxation and are unaffected by exposure of ASM to pharmacological inhibitors of PKA [57].

\section{Gi-coupled receptors}

The majority of known GPCRs preferentially couple to members of the Gi family, and Gi appears to be the most abundantly expressed heterotrimeric $\mathrm{G}$ protein in most cell types. Members of the Gai family expressed in ASM include Gai-1, Gai-2, and Gai-3 [58,59]. Gai activation is typically associated with inhibition of Gas-stimulated AC activity (for certain $\mathrm{AC}$ isoforms) and thus reduced cAMP generation, the functional consequences of which should be predictable but are often difficult to identify in a wide range of experimental models $[2,60]$. However, numerous other signaling events elicited by Gai activation, with clear functional consequences, have recently been identified (Fig. 3). Gi appears capable of activating Rho through activation of Rho guanine nucleotide exchange factors (GEFs), and in ASM this can mediate both actin polymerization and possibly contractile sensitization $[40,61]$. Whether Gi activation of Rho is mediated by $\alpha$ or $\beta \gamma$ subunits is unclear. $\beta \gamma$ subunits released due to $\mathrm{Gi}$ activation are believed to promote many of the $\beta \gamma$ effects identified to date, perhaps reflecting the relatively high levels of $\mathrm{Gi}$ in most cells that could provide the levels of free $\beta \gamma$ required for its signaling effect [52]. In in vitro systems $\beta \gamma$ subunits have been shown to enhance the activity of selected AC isoforms stimulated by $\mathrm{G} \alpha \mathrm{s}$. Moreover, $\beta \gamma$ may also mediate, through what may be an indirect mechanism [62], the AC sensitization observed in neuronal cells chronically exposed to opioids (contributing to tolerance to morphine [63-65]) and in human ASM cells chronically treated with carbachol and other ligands capable of activating Gi-coupled receptors [46]. The purpose of such AC sensitization in ASM is unclear, but may involve the need to maintain a degree of Gs-coupled receptor signaling in the face of persistent Gi-coupled receptor activation.
A role for Gi-coupled receptors in modulating growth in ASM is suggested by studies that demonstrate that pertussis toxin (which ADP-ribosylates and inhibits Gai) partially inhibits ASM DNA synthesis stimulated by numerous GPCR ligands including carbachol (activating the $\mathrm{m} 2$ $\mathrm{mAChR}), \mathrm{LPA}, \mathrm{SPP}$, endothelin, and thrombin $[18,38]$. The mechanism mediating Gi-stimulated growth of ASM is unclear, although actions of both $\alpha$ and $\beta \gamma$ subunits may be involved. G $\beta \gamma$ has the potential to stimulate p42/p44 MAPK via activation of PLC and PKC, and can also mediate p42/ p44 activation through Src-dependent transactivation of the epidermal growth factor (EGF) receptor [66]. However, none of these mechanisms has been established in ASM. On the contrary, transactivation of the EGF receptor is not induced by thrombin, carbachol, or LPA in human ASM cultures, and increased p42/p44 MAPK signaling does not appear to mediate the synergistic effect of several GPCR agonists on EGF-stimulated ASM growth $[18,19]$. These latter findings suggest potentially novel mitogenic signaling events and define cooperativity between GPCRs and receptor tyrosine kinases in mediating ASM growth.

\section{$\mathbf{G}_{12 / 13}$ coupled receptors}

Signaling via activation of the $G_{12 / 13}$ family has not been characterized as extensively as has that by other heterotrimeric $G$ proteins. The effector molecules that interact directly with $G_{12}$ and $G_{13}$ are not well established, with the exception of members of a family of guanine nucleotide exchange factors for the small $G$ protein Rho [67]. The GPCRs capable of activating $G_{12}$ or $G_{13}$ are also unclear. Immunoblot analysis demonstrates $G \alpha_{12}$ and $G \alpha_{13}$ protein in rat bronchial smooth muscle tissue, and levels are elevated by repeated antigen challenge (see below) [68]. In ASM cells, those GPCRs activating $\mathrm{G}_{12 / 13}$ have not been characterized, although SPP/LPA-activated EDG receptors, thrombin-activated PAR receptors, and TP receptors are candidates. The profound effect of inhibitors of Rho and Rho kinase on GPCR-mediated changes in contractile sensitization $[69,70]$ and actin polymerization [40] strongly suggest a physiologic role for $\mathrm{G}_{12 / 13}$ signaling in ASM.

\section{Regulation of GPCR signaling}

Signaling by GPCRs is a highly regulated process. One critical way in which a cell controls its response to extracellular GPCR ligands is through regulation of the expression and activity of each component of the GPCR-G protein-effector pathway. Either a loss (desensitization) or increase (sensitization) in responsiveness of transmembrane signaling components can be evoked to presumably preserve the cell/organism from excessive signals or ensure detection and reaction to infrequent or minimal signals. In ASM, studies of regulation of GPCR signaling have focused on changes that occur in receptor and $\mathrm{G}$ protein expression and second messenger generation in cells, or on altered contractile/relaxant effects on ASM in vivo or ex vivo. No 
Figure 3

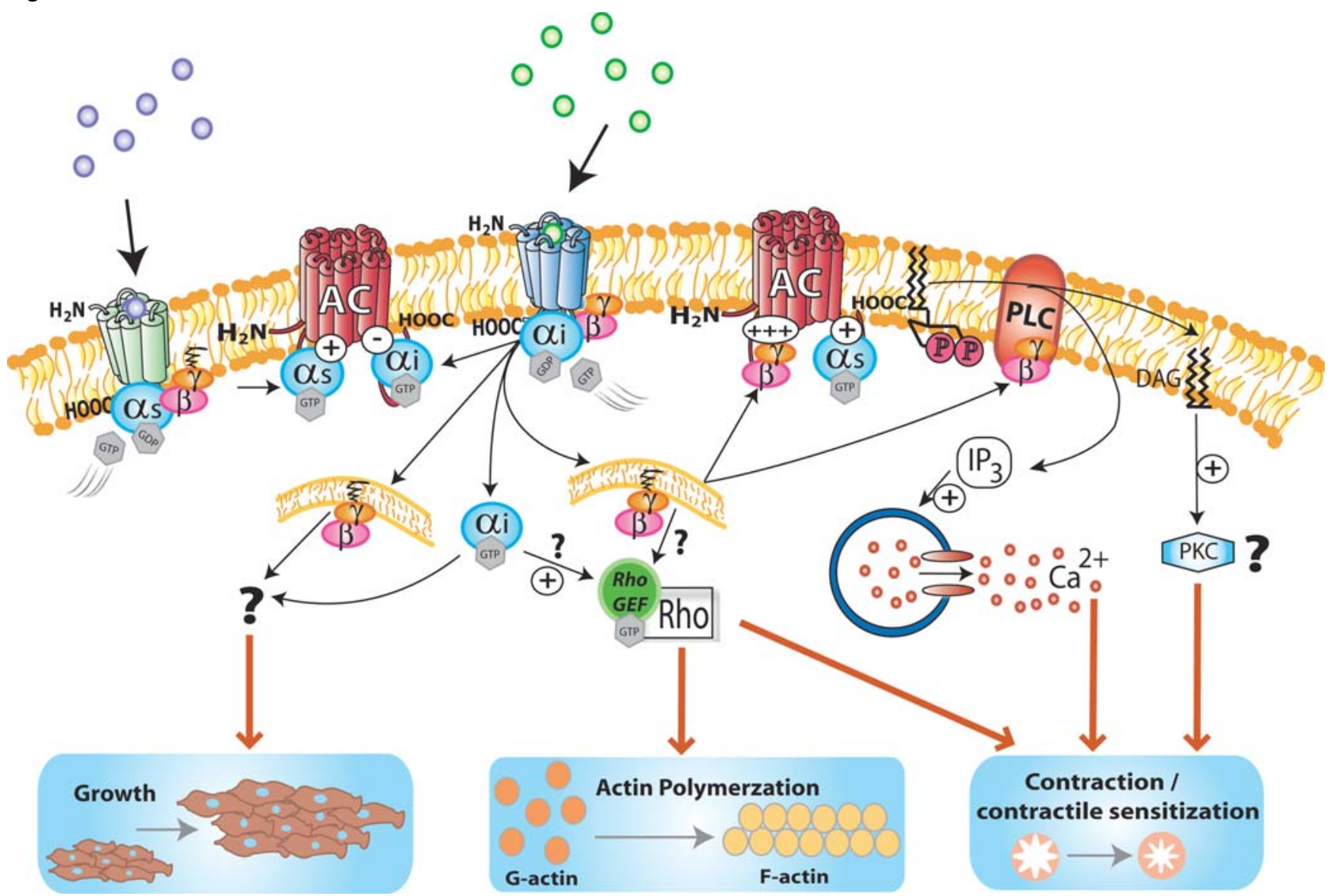

Gi-coupled receptor signaling in airway smooth muscle. Gi-coupled receptors have the capacity to initiate or modulate signaling through the actions of both Gi-derived $\alpha$ and $\beta \gamma$ subunits. Activated Gai dissociates from the heterotrimeric complex and binds to adenylyl cyclase (AC) V and VI to act as a negative modulator of Gas-induced signaling. G $\beta \gamma$ subunits modulate $A C$ activity in an isoform-specific manner, inhibiting $A C$ type I but enhancing Gas-induced activation of AC II, IV and VII. G $\beta \gamma$ can also activate phospholipase C beta (PLC $\beta$ ) isoforms, resulting in phosphoinositide generation, protein kinase C (PKC) activation via 1,2-diacylglycerol (DAG), and calcium mobilization. Through ill-defined mechanisms, Gi-coupled receptor activation can also promote airway smooth muscle (ASM) growth [18], and cooperate with both other G protein-coupled receptors (GPCRs) $[277,278]$ and receptor tyrosine kinases $[19,243]$ to synergistically stimulate growth. Lastly, Gi activation in ASM can contribute to Rhodependent changes in actin polymerization $[40,279,280]$ and calcium sensitization [273], although the mechanism of Rho activation by Gi in ASM (or other cell types) is not well established.

studies to date have considered the effect of desensitization or sensitization of GPCR signaling on GPCR-mediated functions in ASM other than contraction.

\section{Regulation at the receptor locus}

Changes in expression or activity of the receptor represent a powerful means of regulating GPCR signaling. Altered GPCR responsiveness can occur via altered receptor density (up- or down- regulation), modifications of the receptor such as phosphorylation that diminishes receptor-G protein interaction (uncoupling), and trafficking of receptor away from $G$ protein (sequestration/internalization) that enables either recycling of receptor to a responsive form or facilitates receptor loss by lysosomal degradation (Figure 4).
These mechanisms have been characterized extensively in studies of the $\beta_{2} A R$. The degree to which they apply to other GPCRs is both receptor- and cell-dependent [44]. In ASM cells, upon exposure to their agonist, both the $\beta_{2} A R$ and $A 2 b$ adenosine receptor undergo rapid desensitization $[42,71,72]$, which is defined by a loss in agonist-stimulated cAMP generation, (agonist-specific or homologous desensitization). Rapid beta-agonist-promoted desensitization of the ASM $\beta_{2}$ ARs is mediated primarily by receptor phosphorylation by G protein-coupled receptor kinases (GRKs) [44], which specifically recognize the agonist-occupied form of GPCRs. Numerous GPCRs in various cell types including ASM [72] have been shown to be regulated by GRKs, and GRKs themselves are subject to multiple forms of regula- 


\section{Figure 4}

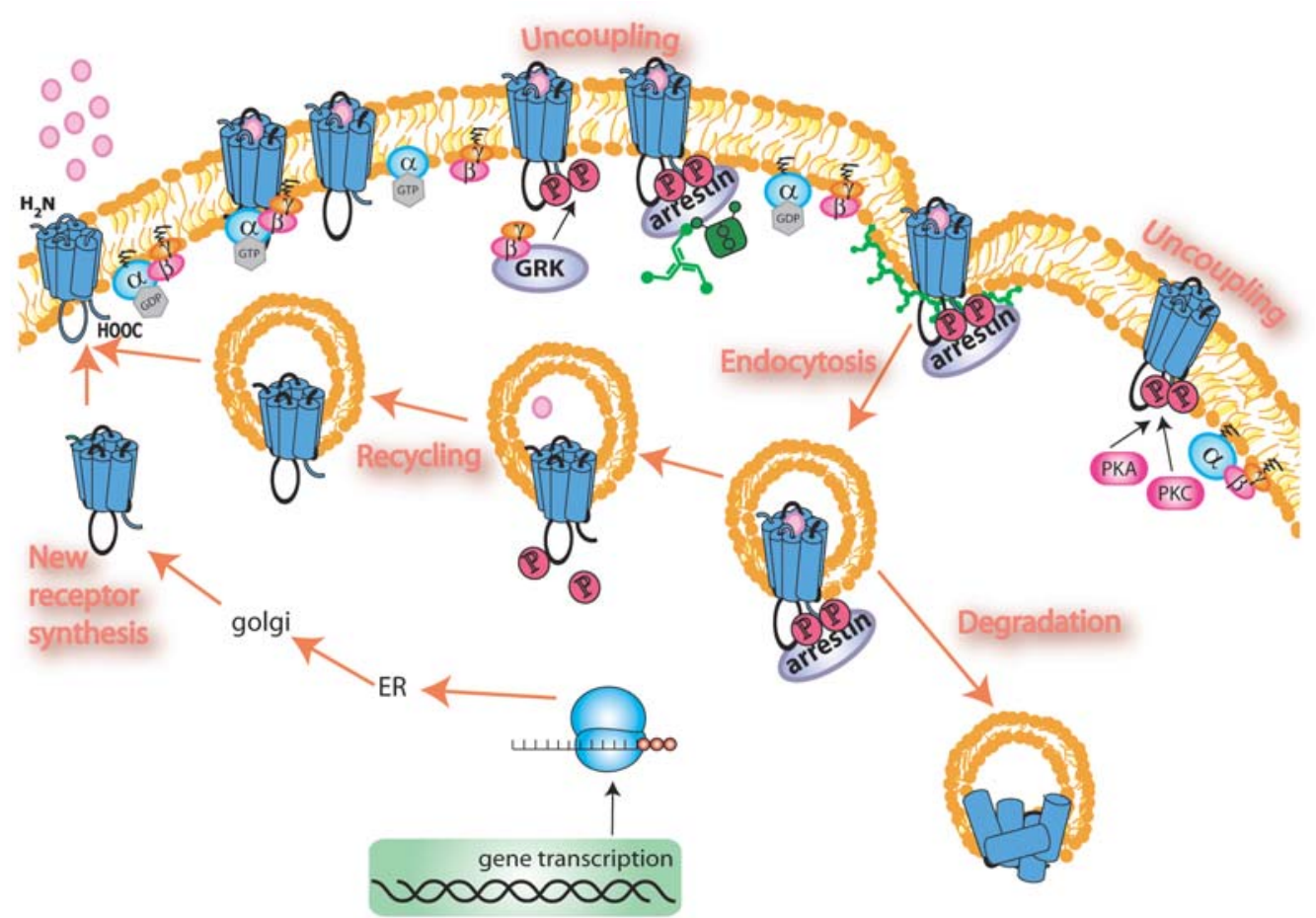

G protein-coupled receptor regulation in airway smooth muscle. Regulation of $\mathrm{G}$ protein-coupled receptor signaling at the receptor locus is effected by numerous mechanisms that establish the number and responsiveness of receptors at the cell surface. These mechanisms include new receptor synthesis, as well as modes of desensitization and resensitization that unfold after a receptor is activated by agonist. Receptor uncoupling occurs as a result of G protein-coupled receptor kinase (GRK) -mediated phosphorylation of agonist-occupied receptor, which promotes arrestin binding to phosphorylated receptor and steric inhibition of GPCR-G protein interaction. Arrestin binding to receptor also initiates internalization of receptor into clathrin-coated pits, after which receptors can traffick to lysosomes for degradation (downregulation) or be dephosphorylated and recycled back to the plasma membrane (resensitization). In addition, activation of intracellular kinases such as protein kinase A (PKA) or protein kinase C (PKC) can also phosphorylate GPCRs and promote a loss of GPCR-G protein coupling. See text for details.

tion, some of which may influence GPCR function in certain disease states (reviewed in [1]). GRK phosphorylation of GPCRs partially uncouples the receptor from $\mathrm{G} \alpha$, and also promotes binding of arrestin molecules to the receptor, which more effectively uncouple the receptor from $G$ protein by sterically inhibiting the receptor-G $\alpha$ interaction [73]. For numerous GPCRs, GRK-mediated arrestin binding also initiates receptor internalization/sequestration, which occurs via the association of the receptor-arrestin complex with components of clathrin-coated pits [74,75]. GPCR internalization is not required for GPCR desensitization, but is required for resensitization, as demonstrated for the $\beta_{2} A R$ in ASM [72]. Interestingly, agonist-stimulated arrestin-dependent internalization of both the $\beta_{2} A R$ and $A 2 b$ adenosine receptor is observed in human ASM cells, whereas ASM EP2 receptors do not readily bind arrestin, do not appear to be phosphorylated by GRKs, and do not undergo rapid agonist-stimulated internalization [20]. Although ASM EP2 receptors do exhibit desensitization with chronic $\mathrm{PGE}_{2}$ treatment, they are much more efficacious in stimu- lating cAMP generation and promoting PKA-dependent functional effects in ASM cells than are either $\beta_{2} A R s$ or $\mathrm{A} 2 \mathrm{~b}$ adenosine receptors ([20] and Pascual and Penn, unpublished observations). These findings demonstrate the receptor-specific nature of mechanisms of homologous desensitization, and also show that susceptibility to desensitization at the receptor locus can be a major determinant in establishing the effect of GPCR ligands and their receptors on cellular functions.

GPCRs are also subject to phosphorylation and desensitization by PKA and PKC. Accordingly, any agent capable of activating cellular PKA or PKC (e.g., other GPCR agonists, phosphodiesterase inhibitors) can diminish GPCR responsiveness. PKA and PKC-mediated phosphorylation causes a degree of receptor uncoupling from $G$ protein, but it does not promote arrestin binding to receptor and rapid internalization. Such heterologous desensitization of a given GPCR is typically not as profound as homologous desensitization. Cultured ASM cells exposed briefly to either $\mathrm{PGE}_{2}$, 
adenosine, forskolin (all stimulators of cAMP production and PKA activation) or phorbol ester (a PKC activator) exhibit diminished isoproterenol-stimulated cAMP production $[42,46,71,72]$. Similarly, chronic exposure of ASM cells to interleukin-1 $\beta$ (IL-1 $\beta$ ), tumor necrosis factor alpha (TNF- $\alpha$ ), or transforming growth factor beta (TGF- $\beta$ ) also results in heterologous desensitization of the $\beta_{2} A R$, presumably via the induction of Cyclo-oxygenase-2 (COX-2) activity and the autocrine effect of induced $P \mathrm{PE}_{2}$ [76-80]. The $\mathrm{PGE}_{2}$ or IL-1 $\beta$-mediated loss of beta-agonist-stimulated second messenger generation is associated with a loss in the relaxant effect of beta-agonist on carbachol-contracted ASM cells in culture [77]. The $\mathrm{H} 1$ histamine receptor exhibits both homologous [81] and heterologous [81] desensitization, the former presumably mediated exclusively by GRKs, the latter induced by phorbol ester in a PKCdependent manner.

Down-regulation, defined as a loss in receptor density, occurs as a result of increased receptor degradation or reduced receptor synthesis. Recovery from GPCR downregulation is a relatively slow process and requires new receptor synthesis. Virtually all GPCRs studied to date undergo some degree of downregulation when chronically exposed to their agonist. Other agents can promote a loss of GPCR density through either inhibition of receptor gene transcription, or via ill-defined mechanisms that promote receptor degradation.

Arrestin-dependent internalization of GPCRs has been identified as a pathway leading to lysosomal degradation of GPCRs [82]. Recently studies also suggest that $\beta_{2} A R s$ and CXCR4 receptors are subject to ubiquitination that ultimately directs internalized receptor to lysosomes $[83,84]$, or in the case of mu and delta opioid receptors, to proteosomal degradation [85]. Chronic exposure of ASM cells to beta-agonist, or ASM tissue to histamine results in downregulation of the $\beta_{2} A R$ [86] and $\mathrm{H} 1$ histamine receptor [87], respectively. The effects of a receptor's agonist and other agents (e.g., glucocortoids, cytokines, beta-agonists) on pre- and post-transcriptional regulation of new receptor synthesis have been characterized for numerous GPCRs in ASM or lung [81,87-97]. Although receptor degradation probably plays a prominent role in the down-regulation of GPCRs in ASM, the trafficking of GPCRs to their degradation fate has not been studied in ASM cells.

Up-regulation of GPCR expression is also observed for numerous GPCRs in numerous cell types and is an important physiologic means of conferring sensitization of GPCR signaling. Increased GPCR expression, mediated by increased gene transcription as well as post-transcriptional mechanisms, is frequently induced experimentally by chronic treatment of cells with antagonist. Antagonist-mediated up-regulation of GPCRs is relatively unexplored in ASM cells or tissue, although chronic treatment of rabbits with atropine has been shown to up-regulate both $\mathrm{m} 2$ and $\mathrm{m} 3$ $\mathrm{mAChRs}$ in the airway [98]. Transcription regulation of most GPCR genes in ASM cells is poorly understood, but should be greatly abetted by the increasing adroitness in applying molecular techniques to primary ASM cultures and by the emergence of models of ASM phenotype regulation $[27,93]$.

One final means by which GPCR responsiveness is influenced is by receptor genotype. Single nucleotide polymorphisms (SNPs) that result in changes in $\beta_{2} A R$ expression, cellular distribution, and signaling have been identified in both the promoter and coding region of the $\beta_{2} A R$ gene $[99,100]$. SNPs identified in the $\beta_{2} A R$ promoter have been shown to affect receptor expression [101,102]. Among those polymorphisms detected in the coding region, Arg $\rightarrow$ Gly16 exhibits enhanced agonist-induced desensitization (of beta-agonist-stimulated cAMP generation) and down-regulation, whereas Gln $\rightarrow$ Glu27 is decidedly desensitization- and down-regulation-resistant. Importantly, these properties are evident in $\beta_{2} A R s$ expressed endogenously in ASM cultures [86]. SNPs identified in other GPCRs (including the $\alpha 2 a-[103], \alpha 2 b-$ [104], and $\beta 1$-adrenergic receptors $[105,106])$ have also been shown to be of functional consequence, although their characterization has been performed primarily in either cell expression models or in the cardiovascular system.

The relevance of $\beta_{2}$ AR SNPs to asthma and asthma therapy are discussed below.

\section{Regulation at the G protein locus}

Regulation of $\mathrm{G}$ protein expression and activity has the potential to modify GPCR signaling. G $\alpha$ subunit GTPase activity is known to be regulated by recently discovered RGS (regulators of $\mathrm{G}$ protein signaling) proteins [107]. Experimental manipulation of RGS protein expression can alter GPCR signaling, but the physiologic role of RGS proteins is unclear. Interestingly, GRK2 has been recently shown to contain an RGS domain that can interact specifically with Gaq and quench its activity [108].

Overexpression of $G \alpha$ subunits in various cell systems can enhance GPCR signaling, and the expression of certain $\mathrm{G} \alpha$ subtypes is altered in various disease state models (see below). In human ASM cells in culture, overexpression of Gas increases both basal and Gs-coupled receptor-mediated cAMP production [46]. Whether altered $\mathrm{G} \alpha$ expression or localization impacts GPCR signaling under physiologic conditions is somewhat controversial. Endogenous expression of $G$ proteins is typically much higher than that of GPCRs or effectors, suggesting that most GPCR-G protein-effector signaling is probably limited more by the expression/activity of the effector or GPCR than by that of the 
G protein [109]. However, a growing appreciation that GPCR signaling may be highly compartmentalized [17] suggests that even small changes in $\mathrm{G} \alpha$ subtype expression may regulate GPCR signaling. Consistent with this notion are observations that exposure of lung [110-112], ASM strips ex vivo [113,114], or ASM cultures [50] to various agents can elicit a loss of $\beta_{2} A R$ function that is associated with increased expression of specific Gai isoforms or decreased expression of Gas.

\section{Regulation at the effector locus}

Although the study of endogenously-expressed GPCR effectors lags behind that of GPCRs and heterotrimeric G proteins, the recent cloning of numerous PLC and AC isoforms and their analysis in expression systems has facilitated insight into the tremendous complexity of effector regulation. Multiple mechanisms by which PLC activity is regulated have been demonstrated [115]. PLC $\beta$ activity is greatly influenced by substrate availability; the agonist-sensitive pool of $\mathrm{PIP}_{2}$ is metabolized several times per minute [116], meaning that recycling of products of hydrolysis, and the activity of numerous enzymes involved in this process, is critical to PLC activity. Localization of PLC isoforms to the membrane appears to be regulated by interaction of pleckstrin homology domains in PLC with specific phosphoinositides and G $\beta \gamma$ subunits [117,118]. PLC $\beta 2$ and PLC 33 isoforms can be phosphorylated by PKA, which results in reduced activity [119-121]. Other PLC isoforms can be phosphorylated by PKC, albeit with no apparent consequence [115,122]. Interestingly, activated PLC $\beta$ isoforms serve as GTPase-activating proteins for G $\alpha q$ and thus participate in negative feedback control of their activation [123].

Unfortunately our understanding of PLC regulation is derived largely from studies using cell-free models or cellular expression systems. With the exception of work from Martin and colleagues [124-126] and Pyne and Pyne [127], few studies to date have examined PLC signaling and its regulation in ASM cells.

Studies of $A C$ regulation have been limited by the extremely low levels of endogenous $A C$ isoform expression, and by the unstable nature of the $A C$ protein, which has rendered its purification and characterization problematic. Detection of endogenous AC protein with currently available antibodies is often difficult in many cell types (including ASM), despite the suggestion of specific isoform expression in parallel analyses of AC mRNA levels. However, expression of recombinant $A C$ isoforms has helped identify some regulatory features of AC $[45,128,129]$. AC I, II, III, V, and VII are subject to phosphorylation by PKC, which results in their sensitization [130-134]. Conversely, phosphorylation of $A C V$ and $V I$ by PKA inhibits AC activity [135-137]. $\beta \gamma$ subunits potentiate the stimulatory effect of $G \alpha$ s subunits on AC II, IV, and VII [138-140]. Calcium/calmodulim is also a physiologic regulator of $A C \mathrm{I}$, III, and VIII; isoforms whose expression tends to be restricted to the brain and olfactory epithelium [128].

Adenylyl cyclase (as well as other elements and regulators of Gs-coupled receptor signaling) and its activity appear to be concentrated in lipid rafts or caveolae, suggesting that compartmentalization serves to facilitate initiation or quenching of GPCR signaling $[141,142]$. Similarly, components of PLC signaling, but not PLC isoforms themselves, are also recovered in caveolin-containing membrane fractions [143].

In ASM, AC regulation is evident but appears species-specific. Stevens et al. [48] and Pyne and Pyne [127,144] demonstrated that bradykinin, platelet-derived growth factor (PDGF), and phorbol ester stimulate cAMP formation in guinea pig ASM, presumably via a PKC-dependent enhancement of AC Il activation by Gas. Chronic treatment of canine ASM cultures with carbachol reduced basal and agonist-stimulated $A C$ activity, an effect that was reversed by PKC inhibition [51]. Similar results were obtained in studies of bovine ASM [50]. In contrast, chronic treatment of human ASM cultures with carbachol (as well as numerous other agonists of Gi-coupled receptors) promoted AC sensitization but in a PKC-insensitive, pertussis-toxin sensitive manner [46]. This manner of AC sensitization has been observed in other cell types including neuronal cells treated chronically with opioids, and appears to be an adaptive response (tolerance) to counteract persistent $\mathrm{Gi}$ signaling $[64,145,146]$. In an analysis of heterologously-expressed $A C$ isoforms in COS cells, Nevo et al [147] determined that chronic Gi activation resulted in sensitization of $A C I, V, V I$, and VIII, and reduced activity of AC II, IV, and VII. Thus, the profile of $A C$ transcripts and regulatory features of $A C$ in human $A S M$ suggest a predominance of $A C \mathrm{VI}$ or $\mathrm{V}$ in human ASM, whereas PKC-sensitive isoforms, perhaps AC II, may be preferentially expressed in non-human ASM.

\section{Aberrant GPCR signaling and airway hyperreactivity}

Changes in airway structure and ASM contractile state are the principal causes of increased airway resistance in asthma. Altered airway composition and architecture affect airway resistance through mechanisms that are both independent of and complimentary to changes in ASM contractile state. Excessive mucous production and edema are physical impediments to conductance, whereas edema and increased ASM mass alter airway geometry to amplify the effect of ASM contraction on airway lumen diameter [148-154].

ASM contractile state can be viewed as a function of: 1) the net sum of GPCR-mediated signals that result in establish- 
ing the level of the key contractile signaling molecule, calcium; and 2) the response of the cell's contractile machinery to calcium. Figure 5 offers a model that proposes 3 levels at which regulation of GPCR-mediated ASM contraction is altered in asthma.

\section{Altered GPCR agonist presentation}

On one level we can consider the contribution of a disrupted balance of procontractile and prorelaxant stimuli accessible to ASM, whereby 1) an increase in procontractile stimuli in the asthmatic airway promotes greater activation of GPCRs (Gq- and Gi-coupled receptors) mediating contraction, or 2) a reduction in agonist levels serving Gs-coupled receptor activation diminishes prorelaxant signaling. It is well established that numerous GPCR agonists (e.g., acetylcholine, histamine, and thromboxane) capable of evoking ASM contraction are elevated in the airways of many asthmatics [155-159]. The source of these agonists may be neural cells (increased parasympathetic discharge caused by numerous factors) inflammatory cells (e.g., from mast cells, platelets), or possibly resident mesenchymal airway cells (including ASM itself). Exacerbating this condition in asthma is the sloughing of airway epithelium, which constitutes a loss of diffusion barrier and may increase ASM access preferentially to procontractile agonists $[152,160,161]$. These findings strongly suggest that exaggerated procontractile GPCR agonist presentation to ASM occurs with asthma and contributes to increased ASM tone. Less certain is whether the levels of prorelaxant GPCR agonists are suppressed in asthmatics. Such agents (e.g., catecholamines, certain eicosanoids) tend to have short half-lives and their local concentrations are not easily measured. However, it should be recognized that the loss of airway epithelium in asthma also constitutes a loss of relaxant factors that target either GPCRs (e.g. $\mathrm{PGE}_{2}$ ) or other pathways (nitric oxide) in ASM [152,162-164].

\section{Altered GPCR responsiveness to agonist}

On another level we can consider the contribution of altered GPCR responsiveness to a given level of agonist presented to ASM, such that the sum of GPCR-generated signals results in higher than normal increases in intracellular calcium. Such altered GPCR responsiveness may result from either sensitization of Gq- or Gi-mediated signaling that promotes increased calcium flux, or from desensitization of Gs-coupled receptor signaling that antagonizes signaling leading to elevated calcium. Numerous studies suggest that both of these phenomena occur and contribute to ASM hyperresponsiveness.

Recent findings demonstrate that GPCR-mediated contraction of ASM strips ex vivo is augmented by various "sensitization" strategies [165]. These strategies include sensitization to allergen in vivo $[68,112,166,167]$ or prior exposure of ASM strips ex vivo to cytokines, serum from at- opic asthmatics, or immune complexes [113,168-172]. Studies of ASM cells suggest that the observed ASM hyperreactivity results in part from an increased calcium flux mediated by sensitized Gq- or Gi-coupled receptor transmembrane signaling. Treatment of ASM cells with IL-1 $\beta$ or TNF- $\alpha$ causes a significantly greater increase in phosphoinositide generation and calcium flux elicited by carbachol, bradykinin, or thrombin [173-177]. Mechanistic studies suggest that up-regulated receptor or $\mathrm{G}$ protein expression may mediate this enhanced response. IL-1 $\beta$ and TNF- $\alpha$ are both able to increase B2 bradykinin receptor expression in ASM $[174,175]$. Treatment of ASM ex vivo with cytokines, rhinovirus, or asthmatic serum $[114,171,178]$, in vivo with antigen or IL-1 $\beta[112,179]$, or ASM cells in culture with TNF- $\alpha$ [180], has been shown to increase expression of either $\mathrm{Gq}$ or specific Gai isoforms in either lung or ASM. These latter findings are consistent with the observation in ASM cells that calcium mobilization stimulated by $\mathrm{NaF}(\mathrm{a}$ nonspecific $G \alpha$ activator) is increased following chronic treatment with TNF- $\alpha$, and suggest a mechanism by which calcium flux stimulated by numerous GPCRs may be augmented [181]. However, it should be noted that the effects of cytokines on GPCR-mediated PLC activity can be receptor-specific; in the same model that demonstrates TNF- $\alpha$ mediated augmentation of bradykinin-stimulated phosphoinositide production, the phosphoinositide response to histamine was depressed, presumably via a COX-dependent, PKA-mediated phosphorylation and desensitization of the $\mathrm{H} 1$ histamine receptor [175].

The contribution of desensitized prorelaxant Gs-coupled receptor signaling to airway hyperresponsiveness in asthma is unclear. To date, the $\beta_{2} A R$ is the only Gs-coupled receptor whose role in asthma has received significant attention, and the preponderance of evidence suggests that $\beta_{2}$ ARs on ASM are most responsible for the effect of beta-agonists on airway tone [182]. Whether $\beta_{2} A R$ dysfunction, and specifically $\beta_{2} A R$ dysfunction in ASM, plays a prominent role in asthma has been a hotly debated topic for over thirty years. Asthma triggers such as viral infections can diminish $\beta_{2}$ AR function [183], and numerous animal models of airway inflammation, ex vivo analyses of ASM strips treated with cytokines or asthmatic serum [112,114], and limited data from ASM tissue from severe asthmatics $[184,185]$ have all provided evidence that $\beta_{2}$ AR-mediated relaxant effect and signaling are depressed in asthma. Several possible mechanisms by which the proposed diminished $\beta_{2} A R$ function and signaling occurs can be proposed. The diminished capacity of beta-agonists to inhibit methacholine-induced contraction of ASM strips ex vivo may reflect an increased capacity of $m 2 \mathrm{mAChRs}$ to inhibit beta-agonist-stimulated AC activity (note that asthmatic serum and cytokines upregulate Gai expression). As noted above, several studies also demonstrate that numerous agents (e.g. cytokines, TGF- $\beta, \mathrm{PGE}_{2}$, whose levels are 
Figure 5

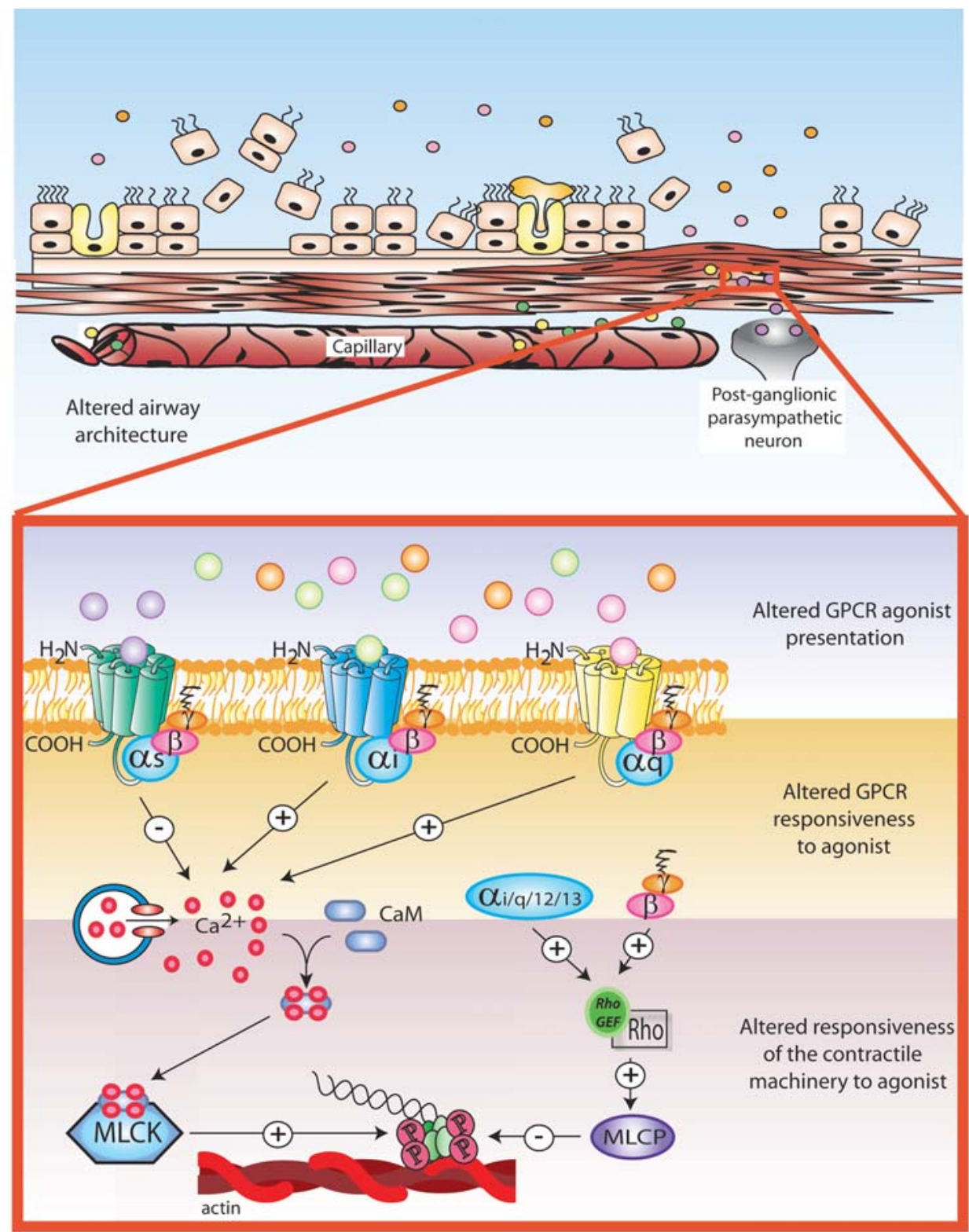

Model of aberrant G protein-coupled receptor signaling in airway smooth muscle contributing to elevated airway smooth muscle tone. Within the context of airway remodeling, G protein-coupled receptor (GPCR) signaling leading to airway smooth muscle (ASM) contraction may be altered at 3 different levels in the asthmatic airway. First, ASM may be exposed to greater levels of GPCR agonists that promote contraction (i.e., those activating Gq- or Gi-coupled receptors), or to lower levels of GPCR agonists that mediate prorelaxant signaling (Gs-coupled receptors). Increased levels of procontractile agonists can augment contraction, whereas combined stimulation of ASM with multiple Gq/Gi -coupled receptor agonists has a synergistic effect on contraction [277]. The sources of both procontractile and prorelaxant agonists include infiltrating inflammatory cells (e.g., mast cells releasing histamine, platelets releasing thrombin), postganglionic neurons with exaggerated cholinergic discharge resulting from stimulated reflex arcs or dysregulated $\mathrm{m} 2$ muscarinic acetylcholine receptor (mAChR) -mediated feedback inhibition [281], and resident airway cells such as epithelium, fibroblasts, and ASM itself. Access of these agonists to ASM may be increased by sloughing of airway epithelium. Second, Gq- or Gi-coupled receptor signaling may be sensitized, or Gs-coupled receptor signaling desensitized, resulting in an imbalance of signaling promoting increased phosphoinositide generation and increased calcium mobilization. Third, the contractile response to calcium may be exaggerated due to "augmented sensitization" manifested in increased myosin light chain phosphorylation caused by: 1) an imbalance of GPCR-derived signals; and 2) increased expression and activity of myosin light chain kinase (MLCK) associated with inhibited myosin light chain phosphatase (MLCP) activity, the latter a result of increased RhoA activity mediated by upregulated $\mathrm{G}_{12 / 13}$ and RhoA expression. Not included in this model (for the sake of simplicity) are other potential regulatory features of ASM contraction including ASM strain and load, direct contribution of non-GPCR signaling pathways to phospholipase C (PLC) activation and calcium mobilization, calcium loading in intracellular stores, compartmentalization of calcium and calcium signaling, and ion channel and membrane pump activity that directly and indirectly affect intracellular calcium levels. 
elevated in the asthmatic airway) induce desensitization of the $\beta_{2} A R$ in cultured ASM cells, typically by mechanisms suggestive of PKA-mediated $\beta_{2} A R$ phosphorylation. Moreover, intratracheal installation of IL- $1 \beta$ in rats results in not only a loss of beta-agonist-mediated relaxation of methacholine-induced bronchoconstriction, but an increase in GRK activity, and GRK2 and GRK5 expression in the lung [112]. This is an intriguing finding and suggests that inflammation may modulate homologous GPCR desensitization in the airway. This may preferentially affect $\beta_{2} A R$ signaling in ASM, in light of findings by McGraw et al. suggesting that low (endogenous) expression levels of GRKs in ASM cells account for relatively robust $\beta_{2} A R$ signaling in ASM [186], and that such signaling may be sensitive to changes in GRK [72] or arrestin [20] expression.

In contrast to the evidence cited above, numerous studies have noted no appreciable loss of $\beta_{2}$ AR function in asthmatics based on analyses of lung function, or tissues ex vivo (reviewed in $[2,4,187]$ ). Moreover, $\beta_{2}$ AR blockade in normal subjects does not cause bronchoconstriction [188,189], and the Arg $\rightarrow$ Gly16 (desensitization-prone) $\beta_{2} A R$ polymorphism is not over-represented in asthmatics [190]. These findings suggest that asthma is not defined by diminished $\beta_{2} A R$ responsiveness. However, constitutive $\beta_{2} A R$ signaling does appear to be important in the asthmatic subject, as administration of $\beta_{2} A R$ antagonists is not well tolerated in many asthmatic subjects [189]. Predictably, diminished $\beta_{2} A R$ function could influence disease severity. Results from both clinical trials and epidemiological studies suggest that $\beta_{2} A R$ SNPs at codon 16 influence $\beta_{2} A R$ responsiveness to both endogenous and exogenous beta-agonists and thereby influence disease severity and response to therapy [99,191,192]. Asthmatics homozygous for Gly16 may have fewer responsive $\beta_{2} A R s$ as a result of greater down-regulation caused by endogenous catecholamines. Consequently, the effects of endogenous catecholamines and the initial response to exogenous betaagonist may be diminished in these patients, as suggested by data from Martinez et al., demonstrating a significantly greater bronchodilator response in (beta-agonist naïve) Arg16 homozygotes [192]. Alternatively, continuous use of inhaled beta-agonists results in a progressive drop in morning peak flow only in patients homozygous for the Arg16 SNP [193], suggesting that the absolute loss of $\beta_{2}$ AR responsiveness is greater in Arg16 homozygotes because of their greater capacity to down-regulate from the (naïve) untreated state.

Thus the collective evidence suggests that $\beta_{2} A R$ dysfunction of any nature does not cause asthma, but the active disease state likely promotes a loss of $\beta_{2} A R$ function that has a small impact on disease severity, at least in some subset of asthmatics. As a corollary, $\beta_{2} A R$ polymorphisms that diminish $\beta_{2} A R$ signaling are disease modifiers, but not dis- ease predictors, and influence the response to therapy. In contrast, a more significant role in asthma is suggested for sensitized $\mathrm{Gq}$ or Gi-coupled receptor signal transduction that promotes a greater phosphoinositide generation and calcium mobilization in response to a given concentration of agonist.

\section{Altered responsiveness of the contractile machinery to calcium}

On a final level we can propose a role for altered responsiveness of ASM contractile machinery to calcium as a mechanism of airway hyperresponsiveness. Although Rhomediated sensitization to calcium occurs within the context of ASM contraction under normal conditions, there is evidence that calcium sensitization mechanisms may be primed ("augmented sensitization") by inflammation. Chiba et al. noted that acetylcholine-induced isometric tension was greater in bronchial rings from antigen-challenged rats compared to that from control rats, although no significant difference between the two groups in calcium mobilization is observed [194]. Similarly, when calcium concentrations were clamped to $1 \mu \mathrm{M}$ in permeabilized bronchial rings, tension development was greater in rings from allergen sensitized/challenged rats compared to that from controls [70]. Changes in the expression of numerous proteins may underlie this augmentation of calcium sensitization in ASM. In tracheal and bronchial smooth muscle from ragweedsensitized dogs, a constitutive increase in phosphorylation of myosin light chain 20 (MLC20) associated with increased content and activity of MLCK $[195,196]$, and human bronchial rings sensitized with allergen ex vivo exhibit an $~ 3$ fold increase in MLCK expression [197]. RhoA protein levels are increased, and acetylcholine-induced translocation of RhoA to the plasma membrane is significantly higher in bronchial smooth muscle from airway hyperresponsive versus control rats [70,198]. Finally, $\mathrm{G} \alpha_{12}$ and $\mathrm{G} \alpha_{13}$ (upstream regulators of Rho activity) levels in bronchial smooth muscle are also upregulated in hyperresponsive rats [68]. These data suggest that allergen-driven inflammation up-regulates multiple proteins in the pathway promoting Rho-dependent calcium sensitization, and that augmented calcium sensitization may be sufficient to confer airway hyperreactivity in asthma.

\section{Altered GPCR responsiveness with therapy}

To further complicate the relationship between GPCR responsiveness and asthma, evidence suggests that both glucocorticoids and beta-agonists, the two most widely used drugs in the treatment of asthma, also regulate GPCR responsiveness, primarily via changes in receptor expression and coupling. Glucocorticoids have been shown to upregulate $\beta_{2} A R$ and $G \alpha$ s expression $[89,91,199]$, counteract the $\beta_{2} A R$ down-regulation induced by beta-agonist [92], and reverse increases in GRK activity and $\beta_{2} A R$ desensitization induced in a rat model of airway inflammation 
[58]. Conversely, glucocorticoids inhibit expression of NK2 receptors in bovine ASM [94], inhibit m2 mAChR expression in the airway [200], and inhibit the IL-1 $\beta$-mediated upregulation of $\mathrm{B} 2$ bradykinin (BK) receptors in the airway [201]. Pretreatment of human ASM cells with glucocorticoids significantly inhibits histamine-stimulated phosphoinositide production [202]. Thus the sum of effects of glucocorticoids on GPCR signal transduction components tends to render ASM less responsive to procontractile stimuli and more responsiveness to beta-agonists.

Beta-agonist therapy, on the other hand, tends to promote the sensitization of procontractile GPCR signaling and desensitization of prorelaxant GPCR signaling, with uncertain clinical relevance. Although conflicting data exist as to whether beta-agonist therapy exacerbates bronchial hyperresponsiveness in asthmatics, Mak and colleagues have recently demonstrated that exposure of ASM ex vivo to betaagonist up-regulates both NK2 [95] and $\mathrm{H} 1$ histamine [90] receptors, suggesting a mechanism whereby enhanced procontractile GPCR signaling promotes bronchial hyperresponsiveness.

Numerous studies have also demonstrated that repeated use of inhaled beta-agonists results in a loss of the prophylactic bronchoprotection conferred by beta-agonists [203206]. In many respects this could be considered a normal and predictable response, consistent with a physiologic/ teleologic role of $\beta_{2} A R$ desensitization and the demonstration of homologous desensitization of ASM $\beta_{2}$ ARs in multiple in vivo, ex vivo, and in vitro models. However, Finney et al. recently observed that lung GRK2 levels were elevated in rats chronically treated with beta-agonists [110]. Thus, in a manner similar to that invoked by IL-1 $\beta$ (see above), chronic beta-agonist therapy may up regulate the GPCR desensitization "machinery" to further limit the effect of therapy and possibly exacerbate disease.

Although the clinical relevance of the observed loss of bronchoprotection has been questioned [207], the collective evidence suggests that homologous $\beta_{2} A R$ desensitization does occur as a consequence of beta-agonist therapy. Accordingly, therapies that minimize or counteract $\beta_{2} A R$ desensitization, such as glucocorticoids and salmeterol, may benefit from this property. Glucocorticoids preserve or enhance $\beta_{2} A R$ function in the airway through both their anti-inflammatory actions as well as their direct effects on ASM $\beta_{2}$ AR expression and regulation noted above. These effects may explain in part the positive cooperativity exhibited by combined beta-agonist and glucocorticoids therapy. As a low intrinsic activity beta agonist, salmeterol has limited capacity to promote homologous $\beta_{2} A R$ desensitization in in vitro models $[208,209]$; this property in addition to its lipophilic nature appears largely responsible for its long-lasting effect. Moreover, daily salmeterol treatment has little effect on the rescue or prophylactic ability of albuterol $[203,210]$.

\section{GPCRs in ASM: What lies ahead}

Within the last decade the field of GPCR signaling has experienced an epiphany with the realization that GPCRs do more than subserve restricted functions in fully differentiated cells; they also play important roles in mediating diverse cell functions such as embryogenesis, tissue regeneration, and cell proliferation $[211,212]$. Interestingly, this realization coincided with a similarly profound discovery in the field of asthma research - that ASM not only contracts, but also performs numerous "synthetic" functions that modulate both airway structure and airway inflammation. Not surprisingly, ASM GPCRs are important regulators of many ASM synthetic functions.

The newfound respective focuses of GPCR signaling and ASM research suggest an exciting direction for the study of GPCRs in ASM over the next decade. The current challenge (or curse) confronting the student of ASM signal transduction extends beyond defining the myriad intracellular signaling pathways, their regulation, and their degree of "cross-talk" with each other, to understanding how these events occur within an equally complex, dynamic airway environment.

Such an understanding should not only greatly improve our knowledge of asthma pathogenesis, but also redefine asthma therapy. With the possible exception of steroids, asthma drugs have been developed and prescribed to prevent or reverse acute bronchospasm with little consideration of their effects on ASM synthetic functions and the chronic nature of asthma. As the roles of airway remodeling and ASM synthetic functions in asthma pathogenesis become more clearly established, agents that target the activation or signaling of various GPCRs that mediate these phenomena will undoubtedly receive greater consideration as prophylactic and therapeutic asthma drugs.

\footnotetext{
Abbreviations

$\mathrm{AA}=$ arachadonic acid

$\mathrm{AC}=$ adenylyl cyclase

$\mathrm{ASM}=$ airway smooth muscle

$\mathrm{BK}=$ bradykinin

$\beta_{2} A R=$ beta-2-adrenergic receptor

$\mathrm{CLT1R}=$ cysteinyl leukotriene type I receptor

$\mathrm{COX} 2=$ cyclo-oxygenase-2

$\mathrm{DAG}=1,2$-diacylglycerol

$E D G=$ endothelium differentiation gene
} 


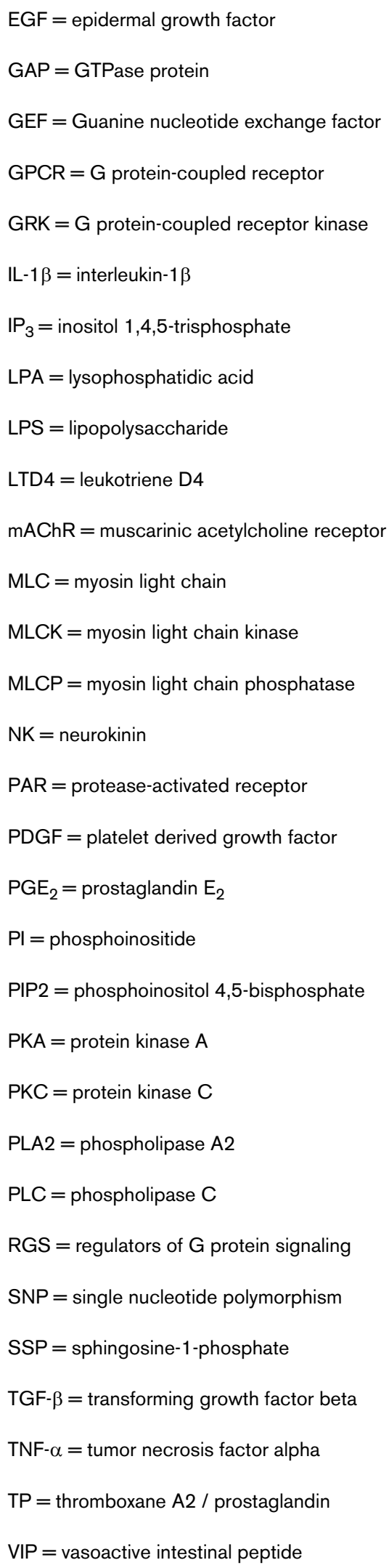

\section{Acknowledgments}

The authors wish to thank numerous investigators including Jim Martin and Judith Mak for providing thoughtful discussion, and Stuart Hirst, Dennis McGraw, Andrew Halayko, Steve Liggett, Steve Peters, and lan Hall for their critical review of the manuscript and contributions leading to its final form. The authors would also like to acknowledge the contributions of Emma Weaver, who was largely responsible for figure generation, and for whom we have reserved a place in our lab as soon as she graduates from high school, college, and medical school. At that time we hope she will be supported by NIH grants HL58506, HL65338, and HL67663. R.B.P. is recipient of an American Lung Association Career Investigator Award.

\section{References}

1. Penn RB, Pronin AP, Benovic JL Regulation of G protein-coupled receptor kinases Trends Cardiovasc Med 2000, 10:81-89

2. Barnes PJ Pharmacology of airway smooth muscle Am J Respir Crit Care Med 1998, 158(Suppl):S123-S132

3. Hall IP Second messengers, ion channels and pharmacology of airway smooth muscle Eur Respir J 2000, 15:1120-1127

4. Douglas JS Receptors on target cells. Receptors on airway smooth muscle Am Rev Respir Dis 1990, 141(Suppl):S123S126

5. Tschumperlin DJ, Drazen JM Mechanical stimuli to airway remodeling Am J Respir Crit Care Med 2001, 164(Suppl):S90S94

6. Bjorck T, Gustafsson LE, Dahlen SE Isolated bronchi from asthmatics are hyperresponsive to adenosine, which apparently acts indirectly by liberation of leukotrienes and histamine $A m$ Rev Respir Dis 1992, 145:1087-1091

7. Forsythe $\mathrm{P}$, Ennis M Adenosine, mast cells and asthma Inflamm Res 1999, 48:301-307

8. Salvatore CA, Tilley SL, Latour AM, Fletcher DS, Koller BH, Jacobson MA Disruption of the $A[3]$ adenosine receptor gene in mice and its effect on stimulated inflammatory cells $\mathrm{J} \mathrm{Biol} \mathrm{Chem}$ 2000, 275:4429-4434

9. Tilley SL, Wagoner VA, Salvatore CA, Jacobson MA, Koller BH Adenosine and inosine increase cutaneous vasopermeability by activating A[3] receptors on mast cells J Clin Invest 2000, 105:361-367

10. Feoktistov I, Garland EM, Goldstein AE, Zeng D, Belardinelli L, Wells JN, Biaggioni I Inhibition of human mast cell activation with the novel selective adenosine $A(2 B)$ receptor antagonist 3-isobutyl-8-pyrrolidinoxanthine (IPDX)[2] Biochem Pharmacol 2001, 62:1163-1173

11. Zhong H, Chunn JL, Volmer JB, Fozard JR, Blackburn MR Adenosine-mediated mast cell degranulation in adenosine deaminase-deficient mice J Pharmacol Exp Ther 2001, 298:433-440

12. Hall IP, Kotlikoff M Use of cultured airway myocytes for study of airway smooth muscle $A m$ J Physiol 1995, 268:L1-L11

13. Panettieri RA, Murray RK, DePalo LR, Yadvish PA, Kotlikoff MI A human smooth muscle cell line that retains physiological responsiveness Am J Physiol 1989, 256(Cell Physiol 25):C329C335

14. Murray RK, Fleischmann BK, Kotlikoff Ml Receptor-activated $\mathrm{Ca} 2+$ influx in human airway smooth muscle: use of $\mathrm{Ca} 2+\mathrm{im}$ aging and perforated patch-clamp techniques Am J Physio 1993, 264(Cell Physiol 33):C485-C490

15. McGraw DW, Forbes SL, Kramer LA, Witte DP, Fortner CN, Paul RJ, Liggett SB Transgenic overexpression of beta[2]-adrenergic receptors in airway smooth muscle alters myocyte function and ablates bronchial hyperreactivity J Biol Chem 1999, 274:32241-32247

16. Neubig RR Membrane organization in G-protein mechanisms FASEB J 1994, 8:939-946

17. Ostrom RS, Post SR, Insel PA Stoichiometry and compartmentation in $\mathrm{G}$ protein-coupled receptor signaling: implications for therapeutic interventions involving G(s) J Pharmacol Exp Ther 2000, 294:407-412

18. Ediger TL, Danforth BL, Toews ML Lysophosphatidic acid upregulates the epidermal growth factor receptor in human airway smooth muscle cells Am J Physiol Lung Cell Mol Physiol 2002, 282:L91-L98

19. Krymskaya VP, Orsini MJ, Eszterhas A, Benovic JL, Panettieri RA, Penn RB Potentiation of human airway smooth muscle prolif- 
eration by Receptor Tyrosine Kinase and G protein-coupled receptor activation $A m$ J Respir Cell Mol Biol 2000, 23:546-554

20. Penn RB, Pascual RM, Kim Y-M, Mundell SJ, Krymskaya VP, Panettieri RA Jr, Benovic JL Arrestin specificity for G protein-coupled receptors in human airway smooth muscle $J \mathrm{Bio} / \mathrm{Chem}$ 2001, 276:32648-32656

21. Widdop S, Daykin K, Hall IP Expression of muscarinic M2 receptors in cultured human airway smooth muscle cells $A m J$ Respir Cell Mol Biol 1993, 9:541-546

22. Halayko AJ, Salari H, Ma X, Stephens NL Markers of airway smooth muscle cell phenotype Am J Physiol 1996, 270:L1040L1051

23. Hubmayr RD, Shore SA, Fredberg JJ, Planus E, Panettieri RA Jr, Moller W, Heyder J, Wang N Pharmacological activation chang es stiffness of cultured human airway smooth muscle cells $A m$ J Physiol 1996, 271:C1660-C1668

24. Stephens NL, Li W, Wang Y, Ma X The contractile apparatus of airway smooth muscle. Biophysics and biochemistry $A m \mathrm{~J}$ Respir Crit Care Med 1998, 158:S80-S94

25. Mitchell RW, Halayko AJ, Kahraman S, Solway J, Wylam ME Selective restoration of calcium coupling to muscarinic $M[3]$ receptors in contractile cultured airway myocytes $A m$ J Physiol Lung Cell Mol Physiol 2000, 278:L1091-L1100

26. Camoretti-Mercado B, Liu HW, Halayko AJ, Forsythe SM, Kyle JW Li B, Fu Y, McConville J, Kogut P, Vieira JE, Patel NM, Hershenson MB, Fuchs E, Sinha S, Miano JM, Parmacek MS, Burkhardt JK, Solway J Physiological control of smooth muscle-specific gene expression through regulated nuclear translocation of serum response factor $J$ Biol Chem 2000, 275:30387-30393

27. Halayko AJ, Solway J Molecular mechanisms of phenotypic plasticity in smooth muscle cells J App/ Physio/ 2001, 90:358 368

28. Johnson EN, Druey KM Heterotrimeric G protein signaling: role in asthma and allergic inflammation $J$ Allergy Clin Immunol 2002, 109:592-602

29. Rhee SG Regulation of phosphoinositide-specific phospholipase C Annu Rev Biochem 2001, 70:281-312

30. Pohl J, Winder SJ, Allen BG, Walsh MP, Sellers JR, Gerthoffer WT Phosphorylation of calponin in airway smooth muscle $A m$ Physiol 1997, 272:L115-L123

31. Hakonarson H, Grunstein MM Regulation of second messengers associated with airway smooth muscle contraction and relaxation Am J Respir Crit Care Med 1998, 158:S115-S122

32. Giembycz MA, Raeburn D Current concepts on mechanisms of force generation and maintenance in airways smooth muscle Pulm Pharmacol 1992, 5:279-297

33. Somlyo AP, Somlyo AV Signal transduction and regulation in smooth muscle Nature 1994, 372:231-236

34. Hauck RW, Schulz C, Schomig A, Hoffman RK, Panettieri RA Jr alpha-Thrombin stimulates contraction of human bronchial rings by activation of protease-activated receptors $A m$ Physiol 1999, 277:L22-L29

35. Toews ML, Ediger TL, Romberger DJ, Rennard SI Lysophospha tidic acid in airway function and disease Biochim Biophys Acta 2002, 1582:240-250

36. Page $\mathrm{K}$, Hershenson MB Mitogen-activated signaling and cell cycle regulation in airway smooth muscle Front Biosci 2000 5:D258-D267

37. Krymskaya VP, Penn RB, Orsini MJ, Scott PH, Plevin RJ, Walker TR, Eszterhas AJ, Amrani Y, Chilvers ER, Panettieri RA Jr Phosphatidylinositol 3-kinase mediates mitogen-induced human airway smooth muscle cell proliferation $A m$ J Physiol 1999 , 277:L65-L78

38. Ammit AJ, Hastie AT, Edsall LC, Hoffman RK, Amrani Y, Krymskaya VP, Kane SA, Peters SP, Penn RB, Spiegel S, Panettieri RA Jr Sphingosine 1-phosphate modulates human airway smooth muscle cell functions that promote inflammation and airway remodeling in asthma $F A S E B J$ 2001, 15:1212-1214

39. Pang L, Knox AJ PGE2 release by bradykinin in human airway smooth muscle cells: involvement of cyclooxygenase-2 induction $A m$ J Physiol 1997, 273:L1132-L1140

40. Hirshman CA, Emala CW Actin reorganization in airway smooth muscle cells involves $\mathbf{G q}$ and $\mathbf{G i}-2$ activation of Rho $A m$ J Physiol 1999, 277:L653-L661

41. Belvisi MG, Saunders M, Yacoub M, Mitchell JA Expression of cyclo-oxygenase-2 in human airway smooth muscle is associat- ed with profound reductions in cell growth $\mathrm{Br} J$ Pharmacol 1998, 125:1102-1108

42. Mundell SJ, Olah ME, Panettieri RA, Benovic JL, Penn RB Regulation of $\mathrm{G}$ protein-coupled receptor-adenylyl cyclase responsiveness in human airway smooth muscle by exogenous and endogenous adenosine $A m$ J Respir Cell Mol Biol 2000, 24:155-163

43. Maruno K, Absood A, Said SI VIP inhibits basal and histaminestimulated proliferation of human smooth muscle cells. American Journal of Physiology 1995, 268:L1047-L1051

44. Penn RB, Benovic JL Regulation of $\mathbf{G}$ protein-coupled receptors. In Handbook of Physiology (Edited by: Conn PM) New York: Oxford University Press 1998, 125-164

45. Premont RT Identification of adenylyl cyclases by amplification using degenerate primers Methods Enzymol 1994, 238:116127

46. Billington CK, Hall IP, Mundell SM, Parent J-L, Panettieri RA, Benovic JL, Penn RB Inflammatory and contractile agents sensitize specific adenylyl cyclase isoforms in human airway smooth muscle Am J Resp Cell Mol Biol 1999, 21:597-606

47. Xu D, Isaacs $C$, Hall IP, Emala CW Human airway smooth muscle expresses 7 isoforms of adenylyl cyclase: a dominant role for isoform V Am J Physiol Lung Cell Mol Physiol 2001, 281:L832-L843

48. Stevens PA, Pyne S, Grady M, Pyne NJ Bradykinin-dependent activation of adenylate cyclase activity and cyclic AMP accumulation in tracheal smooth muscle occurs via protein kinase C-dependent and -independent pathways Biochem J 1994, 297:233-239

49. Pyne NJ, Moughal N, Stevens PA, Tolan D, Pyne S Protein kinase C-dependent cyclic AMP formation in airway smooth muscle: the role of type II adenylate cyclase and the blockade of extracellular-signal-regulated kinase-2 (ERK-2) activation Biochemical J 1994, 304:611-616

50. Emala CW, Clancy-Keen J, Hirshman CA Decreased adenylyl cyclase protein and function in airway smooth muscle by chronic carbachol pretreatment Am J Physiol Cell Physiol 2000, 279:C1008-C1015

51. Schears G, Clancy J, Hirshman CA, Emala CW Chronic carbachol pretreatment decreases adenylyl cyclase activity in airway smooth muscle Am J Physiol 1997, 273:L640-7

52. Taussig R, Zimmermann G Type-specific regulation of mammalian adenylyl cyclases by $\mathrm{G}$ protein pathways $A d v$ Second Messenger Phosphoprotein Res 1998, 32:81-98

53. Hallsworth MP, Twort $\mathrm{CH}$, Lee TH, Hirst SJ beta[2]-adrenocepto agonists inhibit release of eosinophil-activating cytokines from human airway smooth muscle cells $\mathrm{Br} J$ Pharmacol 2001, 132:729-741

54. Ammit AJ, Hoffman RK, Amrani Y, Lazaar AL, Hay DWP, Torphy TJ, Penn RB, Panettieri RA TNFa-induced secretion of RANTES and IL-6 from human airway smooth muscle cells: Modulation by cAMP. Am J Respir Cell Mol Biol 2000, 23:794-802

55. Hirshman CA, Zhu D, Panettieri RA, Emala CW Actin depolymerization via the beta-adrenoceptor in airway smooth muscle cells: a novel PKA-independent pathway $A m$ J Physiol Cell Physiol 2001, 281:C1468-C1476

56. Kume H, Hall IP, Washabau RJ, Tagaki K, Kotlikoff MI b-adrenergic agonists regulate $\mathrm{KCa}$ channels in airway smooth muscle by cAMP-dependent and -independent mechanisms J Clin Invest 1994, 93:371-379

57. Spicuzza L, Belvisi MG, Birrell MA, Barnes PJ, Hele DJ, Giembycz MA Evidence that the anti-spasmogenic effect of the betaadrenoceptor agonist, isoprenaline, on guinea-pig trachealis is not mediated by cyclic AMP-dependent protein kinase $\mathrm{Br}$ Pharmacol 2001, 133:1201-1212

58. Mak JCW, Hlsada T, Salmon PJ, Barnes PJ, Chung KF Reversal of IL-1beta-induced up-regulation of G-protein-coupled receptor kinase activity by dexamethasone $A m$ J Respir Care Crit Med 2001, 163:A228

59. Joshi S, Abebe W, Agrawal DK Identification of guanine nucleotide binding regulatory proteins in bovine tracheal smooth muscle Mol Cell Biochem 1996, 154:179-184

60. Zaagsma J, Roffel AF, Meurs H Muscarinic control of airway function Life Sci 1997, 60:1061-1068

61. Chiba $Y$, Sakai $H$, Misawa M Possible involvement of G(i3) protein in augmented contraction of bronchial smooth muscle 
from antigen-induced airway hyperresponsive rats Biochem Pharmacol 2001, 61:921-924

62. Thomas JM, Hoffman BB Isoform-specific sensitization of adenylyl cyclase activity by prior activation of inhibitory receptors: role of beta gamma subunits in transducing enhanced activity of the type VI isoform Mol Pharmacol 1996, 49:907-914

63. Prather PL, Tsai AW, Law PY Mu and delta opioid receptor desensitization in undifferentiated human neuroblastoma SHSY5Y cells Mol Pharmacol 1994, 270:177-184

64. Nestler EJ, Hope BT, Widnell KL Drug addiction: a model for the molecular basis of neural plasticity Neuron 1993, 11:995-1006

65. Zadina JE, Harrison LM, Ge LJ, Kastin AJ, Chang SL Differential regulation of $\mathrm{mu}$ and delta opiate receptors by morphine, selective agonists and antagonists and differentiating agents in SH-SY5Y human neuroblastoma cells $J$ Pharmacol Exp Ther 1994, 270:1086-1096

66. Luttrell LM, Della Rocca GJ, van Biesen T, Luttrell DK, Lefkowitz RJ Gbetagamma subunits mediate Src-dependent phosphorylation of the epidermal growth factor receptor. A scaffold for G protein-coupled receptor-mediated Ras activation J Bio/ Chem 1997, 272:4637-4644

67. Sah VP, Seasholtz TM, Sagi SA, Brown JH The role of Rho in G protein-coupled receptor signal transduction Annu Rev Pharmacol Toxicol 2000, 40:459-489

68. Chiba $Y$, Misawa M Increased expression of G12 and G13 proteins in bronchial smooth muscle of airway hyperresponsive rats Inflamm Res 2001, 50:333-336

69. lizuka K, Yoshii A, Samizo K, Tsukagoshi H, Ishizuka T, Dobashi K, Nakazawa T, Mori M A major role for the rho-associated coiled coil forming protein kinase in G-protein-mediated $\mathrm{Ca} 2+$ sensitization through inhibition of myosin phosphatase in rabbit trachea $\mathrm{Br} J$ Pharmacol 1999, 128:925-933

70. Chiba Y, Takada Y, Miyamoto S, MitsuiSaito M, Karaki H, Misawa M Augmented acetylcholine-induced, Rho-mediated Ca2+ sensitization of bronchial smooth muscle contraction in antigen-induced airway hyperresponsive rats $\mathrm{Br} J$ Pharmacol 1999, 127:597-600

71. Hall IP, Daykin K, Widdop S Beta 2-adrenoceptor desensitization in cultured human airway smooth muscle Clin Sci (Colch) 1993, 84:151-157

72. Penn RB, Panettieri RA Jr, Benovic JL Mechanisms of acute desensitization of the b2AR-adenylyl cyclase pathway in human airway smooth muscle Am J Resp Cell Mol Biol 1998, 19:338348

73. Lohse MJ, Benovic JL, Codina J, Caron MG, Lefkowitz RJ Beta-arrestin: a protein that regulates beta-adrenergic receptor function Science 1990, 248:1547-1550

74. Ferguson SS, Downey WE 3rd, Colapietro AM, Barak LS, Menard $L$, Caron MG Role of beta-arrestin in mediating agonist-promoted $\mathbf{G}$ protein-coupled receptor internalization Science 1996, 271:363-366

75. Goodman OB Jr, Krupnick JG, Santini F, Gurevich VV, Penn RB, Gagnon AW, Keen JH, Benovic JL Beta-arrestin acts as a clathrin adaptor in endocytosis of the beta2-adrenergic receptor Nature 1996, 383:447-450

76. Huang C, Hepler JR, Chen LT, Gilman AG, Anderson RG, Mumby SM Organization of $G$ proteins and adenylyl cyclase at the plasma membrane Mol Biol Cell 1997, 8:2365-2378

77. Laporte JD, Moore PE, Panettieri RA, Moeller W, Heyder J, Shore SA Prostanoids mediate IL-1 beta-induced beta-adrenergic hyporesponsiveness in human airway smooth muscle cells $\mathrm{Am}$ Physiol 1998, 275:L491-L501

78. Emala CW, Kuhl J, Hungerford CL, Hirshman CA TNF-alpha inhibits isoproterenol-stimulated adenylyl cyclase activity in cultured airway smooth muscle cells Am J Physiol 1997, 272:L644-L650

79. Fong CY, Pang L, Holland E, Knox AJ TGF-beta1 stimulates IL-8 release, COX-2 expression, and PGE[2] release in human airway smooth muscle cells Am J Physiol Lung Cell Mol Physiol 2000, 279:L201-L207

80. Pang L, Holland E, Knox AJ Role of cyclo-oxygenase-2 induction in interleukin-1beta induced attenuation of cultured human airway smooth muscle cell cyclic AMP generation in response to isoprenaline $\mathrm{Br} J$ Pharmacol 1998, 125:1320-1328

81. Pype JL, Mak JC, Dupont LJ, Verleden GM, Barnes PJ Desensitization of the histamine $\mathrm{H} 1$-receptor and transcriptional down- regulation of histamine $\mathrm{H} 1$-receptor gene expression in bovine tracheal smooth muscle $\mathrm{Br} J$ Pharmacol 1998, 125:14771484

82. Gagnon AW, Kallal L, Benovic JL Role of clathrin-mediated endocytosis in agonist-induced down-regulation of the beta2adrenergic receptor J Biol Chem 1998, 273:6976-6981

83. Shenoy SK, McDonald PH, Kohout TA, Lefkowitz RJ Regulation of receptor fate by ubiquitination of activated beta 2 -adrenergic receptor and beta-arrestin Science 2001, 294:1307-1313

84. Marchese A, Benovic JL Agonist-promoted ubiquitination of the G protein-coupled receptor CXCR4 mediates lysosoma sorting J Biol Chem 2001, 276:45509-45512

85. Chaturvedi K, Bandari P, Chinen N, Howells RD Proteasome involvement in agonist-induced down-regulation of $\mathrm{mu}$ and delta opioid receptors J Biol Chem 2001, 276:12345-12355

86. Green SA, Turki J, Bejarano P, Hall IP, Liggett Influence of b2adrenergic receptor genotypes on signal transduction in human airway smooth muscle cells $\mathrm{Am} J$ Respir Cell Mol Biol 1995, 13:25-33

87. Pype JL, Dupont LJ, Mak JC, Barnes PJ, Verleden GM Regulation of H1-receptor coupling and $\mathrm{H} 1$-receptor mRNA by histamine in bovine tracheal smooth muscle $\mathrm{Br} J$ Pharmacol 1998, 123:984-990

88. Mak JC, Rousell J, Haddad EB, Barnes PJ Transforming growth factor-beta1 inhibits beta2-adrenoceptor gene transcription Naunyn Schmiedebergs Arch Pharmacol 2000, 362:520-525

89. Kalavantavanich K, Schramm CM Dexamethasone potentiates high-affinity beta-agonist binding and $\mathrm{g}(\mathrm{s})$ alpha protein expression in airway smooth muscle $A m J$ Physiol Lung Cell Mol Physiol 2000, 278:L1101-L1106

90. Mak JC, Roffel AF, Katsunuma T, Elzinga CR, Zaagsma J, Barnes PJ Up-regulation of airway smooth muscle histamine $H[1]$ receptor mRNA, protein, and function by beta[2]-adrenoceptor activation Mol Pharmacol 2000, 57:857-864

91. Mak JC, Nishikawa M, Barnes PJ Glucocorticosteroids increase beta 2-adrenergic receptor transcription in human lung $A m$ Physiol 1995, 268:L41-L46

92. Mak JC, Nishikawa M, Shirasaki H, Miyayasu K, Barnes PJ Protective effects of a glucocorticoid on downregulation of pulmonary beta 2-adrenergic receptors in vivo J Clin Invest 1995, 96:99-106

93. Forsythe SM, Kogut PC, McConville JF, Fu Y, McCauley JA, Halayko AJ, Liu HW, Kao A, Fernandes DJ, Bellam S, Fuchs E, Sinha S, Bell Gl, Camoretti-Mercado B, Solway J Structure and transcription of the human $\mathrm{m} 3$ muscarinic receptor gene $\mathrm{Am} J$ Respir Cell Mol Bio/ 2002, 26:298-305

94. Katsunuma T, Mak JC, Barnes PJ Glucocorticoids reduce tachykinin NK2 receptor expression in bovine tracheal smooth muscle Eur J Pharmacol 1998, 344:99-106

95. Katsunuma T, Roffel AF, Elzinga CR, Zaagsma J, Barnes PJ, Mak JC beta[2]-adrenoceptor agonist-induced upregulation of tachykinin NK[2] receptor expression and function in airway smooth muscle $A m$ J Respir Cell Mol Biol 1999, 21:409-417

96. Koto H, Mak JC, Haddad EB, Xu WB, Salmon M, Barnes PJ, Chung KF Mechanisms of impaired beta-adrenoceptor-induced airway relaxation by interleukin-1 beta in vivo in the rat $J$ Clin Invest 1996, 98:1780-1787

97. Rousell J, Haddad EB, Mak JC, Webb BL, Giembycz MA, Barnes PJ Beta-Adrenoceptor-medicated down-regulation of M2 muscarinic receptors: role of cyclic adenosine 5'-monophosphatedependent protein kinase and protein kinase $\mathrm{C} \mathrm{Mol} \mathrm{Pharmacol}$ 1996, 49:629-635

98. Witt-Enderby PA, Yamamura HI, Halonen M, Lai J, Palmer JD, Bloom J Regulation of airway muscarinic cholinergic receptor subtypes by chronic anticholinergic treatment $\mathrm{Mol}$ Pharmacol 1995, 47:485-490

99. Liggett SB Pharmacogenetics of beta-1- and beta-2-adrenergic receptors Pharmacology 2000, 61:167-173

100. Hall IP Pharmacogenetics, pharmacogenomics and airway disease Respir Res 2002, 3:10

101. Scott MG, Swan C, Wheatley AP, Hall IP Identification of novel polymorphisms within the promoter region of the human beta2 adrenergic receptor gene $B r J$ Pharmacol 1999, 126:841844

102. McGraw DW, Forbes SL, Kramer LA, Liggett SB Polymorphisms of the $5^{\prime}$ leader cistron of the human beta2-adrenergic recep- 
tor regulate receptor expression J Clin Invest 1998, 102:19271932

103. Small KM, Forbes SL, Brown KM, Liggett SB An asn to lys polymorphism in the third intracellular loop of the human alpha 2A-adrenergic receptor imparts enhanced agonist-promoted Gi coupling J Biol Chem 2000, 275:38518-38523

104. Small KM, Brown KM, Forbes SL, Liggett SB Polymorphic deletion of three intracellular acidic residues of the alpha $2 B$ adrenergic receptor decreases $\mathrm{G}$ protein-coupled receptor kinase-mediated phosphorylation and desensitization $J \mathrm{Bio}$ Chem 2001, 276:4917-4922

105. Mason DA, Moore JD, Green SA, Liggett SB A gain-of-function polymorphism in a G-protein coupling domain of the human beta1-adrenergic receptor $J$ Biol Chem 1999, 274:1267012674

106. Rathz DA, Brown KM, Kramer LA, Liggett SB Amino acid 49 polymorphisms of the human beta1-adrenergic receptor affect agonist-promoted trafficking J Cardiovasc Pharmacol 2002, 39:155-160

107. Ross EM, Wilkie TM GTPase-activating proteins for heterotrimeric G proteins: regulators of G protein signaling (RGS) and RGS-like proteins Annu Rev Biochem 2000, 69:795-827

108. Carman CV, Parent JL, Day PW, Pronin AN, Sternweis PM, Wedegaertner PB, Gilman AG, Benovic JL, Kozasa T Selective regulation of Galpha(q/11) by an RGS domain in the $G$ proteincoupled receptor kinase GRK2 J Biol Chem 1999, 274:3448334492

109. Milligan G, Mullaney I, Kim GD, MacEwan D Regulation of the stoichiometry of protein components of the stimulatory adenylyl cyclase cascade Adv Pharmacol 1998, 42:462-465

110. Finney PA, Belvisi MG, Donnelly LE, Chuang TT, Mak JC, Scorer C, Barnes PJ, Adcock IM, Giembycz MA Albuterol-induced downregulation of Gsalpha accounts for pulmonary beta[2] adrenoceptor desensitization in vivo $J$ Clin Invest 2000, 106:125-135

111. Finney PA, Donnelly LE, Belvisi MG, Chuang TT, Birrell M, Harris A, Mak JC Scorer C, Barnes PJ, Adcock IM, Giembycz MA Chronic systemic administration of salmeterol to rats promotes pulmonary beta[2]-adrenoceptor desensitization and downregulation of $\mathbf{G}(\mathbf{s}$ alpha) $B r J$ Pharmacol 2001, 132:1261-1270

112. Mak JC, Hisada T, Salmon M, Barnes PJ, Chung KF Glucocorticoids reverse IL-1beta-induced impairment of beta-adrenoceptor-mediated relaxation and up-regulation of G-proteincoupled receptor kinases $B r J$ Pharmacol 2002, 135:987-996

113. Hakonarson H, Herrick DJ, Gonzalez Serrano P, Grunstein MM Mechanism of cytokine-induced modulation of b-adrenoceptor responsiveness in airway smooth muscle $J$ Clin Invest 1996, 97:2593-2600

114. Hakonarson H, Herrick DJ, Grunstein MM Mechanism of impaired b-adrenoceptor responsiveness in atopic sensitized airway smooth muscle $A m$ J Physiol 1995, 269(Lung Cell Mol Physiol 13):L645-L652

115. Rebecchi MJ, Pentyala SN Structure, function, and control of phosphoinositide-specific phospholipase C Physiol Rev 2000 80:1291-1335

116. Willars GB, Nahorski SR, Challiss RA Differential regulation of muscarinic acetylcholine receptor-sensitive polyphosphoinositide pools and consequences for signaling in human neuroblastoma cells J Biol Chem 1998, 273:5037-5046

117. Wang T, Dowal L, El-Maghrabi MR, Rebecchi M, Scarlata S The pleckstrin homology domain of phospholipase C-beta[2] links the binding of gbetagamma to activation of the catalytic core $J$ Biol Chem 2000, 275:7466-7469

118. Wang T, Pentyala S, Rebecchi MJ, Scarlata S Differential association of the pleckstrin homology domains of phospholipases C-beta 1, C-beta 2, and C-delta 1 with lipid bilayers and the beta gamma subunits of heterotrimeric $\mathbf{G}$ proteins Biochemis try 1999, 38:1517-1524

119. Yue C, Ku CY, Liu M, Simon MI, Sanborn BM Molecular mechanism of the inhibition of phospholipase $C$ beta 3 by protein kinase C J Biol Chem 2000, 275:30220-30225

120. Liu M, Simon MI Regulation by cAMP-dependent protein kinase of a G-protein-mediated phospholipase C Nature 1996 382:83-87

121. Yue C, Dodge KL, Weber G, Sanborn BM Phosphorylation of serine 1105 by protein kinase $A$ inhibits phospholipase
Cbeta3 stimulation by Galphaq J Biol Chem 1998, 273:1802318027

122. Ryu SH, Kim UH, Wahl MI, Brown AB, Carpenter G, Huang KP, Rhee SG Feedback regulation of phospholipase $\mathbf{C}$-beta by protein kinase C J Biol Chem 1990, 265:17941-17945

123. Berstein G, Blank JL, Jhon DY, Exton JH, Rhee SG, Ross EM Phospholipase C-beta 1 is a GTPase-activating protein for Gq/ 11, its physiologic regulator Cell 1992, 70:411-418

124. Tolloczko B, Tao FC, Zacour ME, Martin JG Tyrosine kinase-dependent calcium signaling in airway smooth muscle cells $\mathrm{Am}$ J Physiol Lung Cell Mol Physiol 2000, 278:L1138-L1145

125. Tao FC, Tolloczko B, Mitchell CA, Powell WS, Martin JG Inositol $(1,4,5)$ trisphosphate metabolism and enhanced calcium mobilization in airway smooth muscle of hyperresponsive rats $A m$ J Respir Cell Mol Biol 2000, 23:514-520

126. Tolloczko B, Turkewitsch $P$, Choudry S, Bisotto S, Fixman ED, Martin JG Src modulates serotonin-induced calcium signaling by regulating phosphatidylinositol 4,5-bisphosphate $A m \mathrm{~J}$ Physiol Lung Cell Mol Physiol 2002, 282:L1305-L1313

127. Pyne S, Pyne NJ Bradykinin-stimulated phosphatidylcholine hydrolysis in airway smooth muscle: the role of $\mathrm{Ca} 2+$ and protein kinase C Biochem J 1995, 311:637-642

128. Taussig R, Gilman AG Mammalian membrane-bound adenylyl cyclases J Biol Chem 1995, 270:1-4

129. Smit MJ, lyengar R Mammalian adenylyl cyclases Adv Second Messenger Phosphoprotein Res 1998, 32:1-21

130. Choi EJ, Wong ST, Dittman AH, Storm DR Phorbol ester stimulation of the type I and type III adenylyl cyclases in whole cells Biochemistry 1993, 32:1891-1894

131. Kawabe J, Ebina T, Toya Y, Oka N, Schwencke C, Duzic E, Ishikawa $Y$ Regulation of type $V$ adenylyl cyclase by PMA-sensitive and -insensitive protein kinase $C$ isoenzymes in intact cells FEBS Lett 1996, 384:273-276

132. Kawabe J, Iwami G, Ebina T, Ohno S, Katada T, Ueda Y, Homcy CJ, Ishikawa $Y$ Differential activation of adenylyl cyclase by protein kinase $C$ isoenzymes J Biol Chem 1994, 269:16554-16558

133. Jacobowitz $O$, lyengar $R$ Phorbol ester-induced stimulation and phosphorylation of adenylyl cyclase 2 Proc Natl Acad Sci U S A 1994, 91:10630-10634

134. Yoshimura M, Cooper DM Type-specific stimulation of adenylyl cyclase by protein kinase C J Biol Chem 1993, 268:4604-4607

135. Premont RT, Jacobowitz O, lyengar R Lowered responsiveness of the catalyst of adenylyl cyclase to stimulation by GS in heterologous desensitization: a role for adenosine $3^{\prime}, 5^{\prime}$-monophosphate-dependent phosphorylation Endocrinology 1992, 131:2774-2784

136. Murthy KS, Zhou H, Makhlouf GM PKA-dependent activation of PDE3A and PDE4 and inhibition of adenylyl cyclase V/VI in smooth muscle Am J Physiol Cell Physiol 2002, 282:C508C517

137. Iwami G, Kawabe J, Ebina T, Cannon PJ, Homcy CJ, Ishikawa Y Regulation of adenylyl cyclase by protein kinase A J Biol Chem 1995, 270:12481-12484

138. Federman AD, Conklin BR, Schrader KA, Reed RR, Bourne HR Hormonal stimulation of adenylyl cyclase through Gi-protein beta gamma subunits Nature 1992, 356:159-161

139. Tang W-J, Gilman AG Type-specific regulation of adenylyl cyclase by $G$ protein bg subunits Science 1991, 254:1500-1503

140. Gao B, Gilman AG Cloning and expression of a widely distributed (type IV) adenylyl cyclase Proc Natl Acad Sci USA 1991, 89:10178-10182

141. Ostrom RS New determinants of receptor-effector coupling: trafficking and compartmentation in membrane microdomains Mol Pharmacol 2002, 61:473-476

142. Ostrom RS, Gregorian C, Drenan RM, Xiang Y, Regan JW, Insel PA Receptor number and caveolar co-localization determine receptor coupling efficiency to adenylyl cyclase $\mathrm{J}$ Biol Chem 2001, 276:42063-42069

143. Hope HR, Pike LJ Phosphoinositides and phosphoinositide-utilizing enzymes in detergent-insoluble lipid domains $\mathrm{Mol} B \mathrm{BiO}$ Cell 1996, 7:843-851

144. Pyne NJ, Pyne S PDGF-stimulated cyclic AMP formation in airway smooth muscle: assessment of the roles of MAP kinase, cytosolic phospholipase A2, and arachidonate metabolites Cell Signal 1998, 10:363-369 
145. Lampert A, Nirenberg M, Klee WA Tolerance and dependence evoked by an endogenous opioid peptide Proc Natl Acad Sci USA 1976, 73:3165-3167

146. Zadina JE, Chang SL, Ge LJ, Kastin AJ Mu opiate receptor downregulation by morphine and up-regulation by naxolone in $\mathrm{SH}$ SY5Y human neuroblastoma cells J Pharmacol Exp Ther 1993, 265:254-262

147. Nevo I, Avidor-Reiss T, Levy R, Bayewitch M, Heldman E, Vogel Z Regulation of adenylyl cyclase isozymes on acute and chronic activation of inhibitory receptors Mol Pharmacol 1998, 54:419426

148. Lemanske RF Jr, Busse WW Asthma JAMA 1997, 278:18551873

149. Chiappara G, Gagliardo R, Siena A, Bonsignore MR, Bousquet J, Bonsignore G, Vignola AM Airway remodelling in the pathogenesis of asthma Curr Opin Allergy Clin Immunol 2001, 1:85-93

150. Fahy JV, Corry DB, Boushey HA Airway inflammation and remodeling in asthma Curr Opin Pulm Med 2000, 6:15-20

151. Hirst SJ, Walker TR, Chilvers ER Phenotypic diversity and molecular mechanisms of airway smooth muscle proliferation in asthma Eur Respir J 2000, 16:159-177

152. Jeffery PK Morphology of the airway wall in asthma and in chronic obstructive pulmonary disease $A m$ Rev Respir Dis 1991, 143:1152-1158

153. Stewart AG Airway wall remodelling and hyperresponsiveness: modelling remodelling in vitro and in vivo Pulm Pharmacol Ther 2001, 14:255-265

154. Martin JG, Duguet A, Eidelman DH The contribution of airway smooth muscle to airway narrowing and airway hyperresponsiveness in disease Eur Respir J 2000, 16:349-354

155. Sofia M, Mormile M, Faraone S, Alifano M, Zofra S, Romano L, Carratu $L$ Increased endothelin-like immunoreactive material on bronchoalveolar lavage fluid from patients with bronchial asthma and patients with interstitial lung disease Respiration 1993, 60:89-95

156. Panettieri RA Airway smooth muscle cell growth and proliferation. In Airway Smooth Muscle: Development, Regulation, and Contractility (Edited by: Raeburn D, Giembycz MA) Basel: Birkhauser Verlag 1994, 41-68

157. Zehr BB, Casale TB, Wood D, Floerchinger C, Richerson HB, Hunninghake GW Use of segmental airway lavage to obtain relevant mediators from the lungs of asthmatic and control subjects Chest 1989, 95:1059-1063

158. Casale TB, Wood D, Richerson HB, Trapp S, Metzger WJ, Zavala D, Hunninghake GW Elevated bronchoalveolar lavage fluid histamine levels in allergic asthmatics are associated with methacholine bronchial hyperresponsiveness J Clin Invest 1987, 79:1197-1203

159. Ackerman V, Carpi S, Bellini A, Vassalli G, Marini M, Mattoli S Constitutive expression of endothelin in bronchial epithelial cells of patients with symptomatic and asymptomatic asthma and modulation by histamine and interleukin-1 J Allergy Clin Immunol 1995, 96:618-627

160. Hamilton LM, Davies DE, Wilson SJ, Kimber I, Dearman RJ, Holgate ST The bronchial epithelium in asthma - much more than a passive barrier Monaldi Arch Chest Dis 2001, 56:48-54

161. Holgate ST Epithelial damage and response Clin Exp Allergy 2000, 30(Suppl 1):37-41

162. Frossard N, Stretton CD, Barnes PJ Modulation of bradykinin responses in airway smooth muscle by epithelial enzymes Agents Actions 1990, 31:204-209

163. Knight DA, Adcock JA, Phillips MJ, Thompson PJ The effect of epithelium removal on human bronchial smooth muscle responsiveness to acetylcholine and histamine Pulm Pharmacol 1990, 3:198-202

164. Raeburn $D$ Putative role of epithelial derived factors in airway smooth muscle reactivity Agents Actions Supp/ 1990, 31:259274

165. Amrani Y, Panettieri RA Jr Modulation of calcium homeostasis as a mechanism for altering smooth muscle responsiveness in asthma Curr Opin Allergy Clin Immunol 2002, 2:39-45

166. Cui ZH, Skoogh BE, Pullerits T, Lotvall J Bronchial hyperresponsiveness and airway wall remodelling induced by exposure to allergen for 9 weeks Allergy 1999, 54:1074-1082

167. Patel HJ, Douglas GJ, Herd CM, Spina D, Giembycz MA, Barnes PJ, Belvisi MG, Page CP Antigen-induced bronchial hyperre- sponsiveness in the rabbit is not dependent on $\mathrm{M}$ [2]-receptor dysfunction Pulm Pharmacol Ther 1999, 12:245-255

168. Schmidt D, Ruehlmann E, Branscheid D, Magnussen $H$, Rabe KF Passive sensitization of human airways increases responsiveness to leukotriene C4 Eur Respir J 1999, 14:315-319

169. Grunstein MM, Hakonarson H, Leiter J, Chen M, Whelan R, Grunstein JS, Chuang S IL-13-dependent autocrine signaling mediates altered responsiveness of IgE-sensitized airway smooth muscle Am J Physiol Lung Cell Mol Physiol 2002, 282:L520-L528

170. Hakonarson H, Herrick DJ, Serrano PG, Grunstein MM Autocrine role of interleukin 1 beta in altered responsiveness of atopic asthmatic sensitized airway smooth muscle J Clin Invest 1997, 99:117-124

171. Hakonarson $\mathrm{H}$, Maskeri N, Carter C, Hodinka RL, Campbell D, Grunstein MM Mechanism of rhinovirus-induced changes in airway smooth muscle responsiveness J Clin Invest 1998 102:1732-1741

172. Hakonarson H, Carter C, Kim C, Grunstein MM Altered expression and action of the low-affinity IgE receptor FcepsilonRII (CD23) in asthmatic airway smooth muscle $J$ Allergy Clin Immunol 1999, 104:575-584

173. Yang CM, Chien CS, Wang CC, Hsu YM, Chiu CT, Lin CC, Luo SF, Hsiao LD Interleukin-1beta enhances bradykinin-induced phosphoinositide hydrolysis and $\mathrm{Ca} 2+$ mobilization in canine tracheal smooth-muscle cells: involvement of the Ras/Raf/mitogen-activated protein kinase (MAPK) kinase (MEK)/MAPK pathway Biochem J 2001, 354:439-446

174. Schmidlin F, Scherrer D, Daeffler L, Bertrand C, Landry Y, Gies JP Interleukin-1beta induces bradykinin $\mathrm{B} 2$ receptor gene expression through a prostanoid cyclic AMP-dependent pathway in human bronchial smooth muscle cells Mol Pharmacol 1998, 53:1009-1015

175. Pype JL, Xu H, Schuermans M, Dupont LJ, Wuyts W, Mak JC Barnes PJ, Demedts MG, Verleden GM Mechanisms of interleukin 1beta-induced human airway smooth muscle hyporesponsiveness to histamine. Involvement of p38 MAPK NFkappaB $A m$ J Respir Crit Care Med 2001, 163:1010-1017

176. Parris JR, Cobban HJ, Littlejohn AF, MacEwan DJ, Nixon GF Tumour necrosis factor-alpha activates a calcium sensitization pathway in guinea-pig bronchial smooth muscle $J$ Physiol 1999, 518:561-569

177. Amrani $\mathrm{Y}$, Chen $\mathrm{H}$, Panettieri RA Activation of tumor necrosis factor receptor 1 in airway smooth muscle: a potential pathway th modulates bronchial hyperresponsiveness in asthma Resp 2000, 1:1-5

178. Hirata F, Lee JY, Sakamoto T, Nomura A, Uchida Y, Hirata A, Hasegawa S IL-1 beta regulates the expression of the Gi2 alpha gene via lipid mediators in guinea pig tracheal muscle $B i$ ochem Biophys Res Commun 1994, 203:1889-1896

179. Lee JY, Uchida Y, Sakamoto T, Hirata A, Hasegawa S, Hirata F Alteration of $\mathrm{G}$ protein levels in antigen-challenged guinea pigs $J$ Pharmacol Exp Ther 1994, 271:1713-1720

180. Hotta K, Emala CW, Hirshman CA TNF-alpha upregulates Gialpha and Gqalpha protein expression and function in human airway smooth muscle cells $A m$ J Physiol 1999, 276:L405-L411

181. Amrani Y, Krymskaya V, Maki C, Panettieri RA Jr Mechanisms underlying TNF-alpha effects on agonist-mediated calcium homeostasis in human airway smooth muscle cells $A m$ Physiol 1997, 273:L1020-L1028

182. Barnes PJ Effect of beta-agonists on inflammatory cells $J$ Allergy Clin Immunol 1999, 104:S10-S17

183. Busse W Infections. In Asthma: basic mechanisms and clinical management (Edited by: Thomson NC) London: Academic Press 1988, 483-502

184. Cerrina J, Le Roy Ladurie M, Labat C, Raffestin B, Bayol A, Brink C Comparison of human bronchial muscle responses to histamine in vivo with histamine and isoproterenol agonists in vitro Am Rev Respir Dis 1986, 134:57-61

185. Goldie RG, Spina D, Henry PJ, Lulich KM, Paterson JW In vitro responsiveness of human asthmatic bronchus to carbachol, histamine, beta-adrenoceptor agonists and theophylline $\mathrm{Br} \mathrm{J} \mathrm{Clin}$ Pharmacol 1986, 22:669-676

186. McGraw DW, Liggett SB Heterogeneity in b-adrenergic receptor kinase in the lung accounts for cell-specific desensitization 
of the b2-adrenergic receptor J Biol Chem 1997, 272:7338 7344

187. Goldie RG Receptors in asthmatic airways $A m$ Rev Respir Dis 1990, 141:S151-S156

188. Barnes PJ Neural control of human airways in health and disease Am Rev Respir Dis 1986, 134:1289-1314

189. Paterson J, Lulich K, Goldie R Drug effects on beta-adrenergic receptor function in asthma in Beta-adrenoceptors in asthma. (Edited by: J Morley) Academic Press: London 1984, 245-268

190. Dewar JC, Wheatley AP, Venn A, Morrison JF, Britton J, Hall IP Beta2-adrenoceptor polymorphisms are in linkage disequilibrium, but are not associated with asthma in an adult population Clin Exp Allergy 1998, 28:442-448

191. Israel $E$ Effect of polymorphism of the beta[2]-adrenergic receptor on response to regular use of albuterol in asthma Int Arch Allergy Immunol 2001, 124:183-186

192. Martinez FD, Graves PE, Baldini M, Solomon S, Erickson R Association between genetic polymorphisms of the beta2-adrenoceptor and response to albuterol in children with and without a history of wheezing J Clin Invest 1997, 100:3184-3188

193. Israel $E$ The effect of polymorphisms of the beta[2]-adrenergic receptor on the response to regular use of albuterol in asthma Am J Respir Crit Care Med 2000, 162:75-80

194. Chiba Y, Sakai H, Suenaga H, Kamata K, Misawa M Enhanced $\mathrm{Ca} 2+$ sensitization of the bronchial smooth muscle contraction in antigen-induced airway hyperresponsive rats Res Commun Mol Pathol Pharmacol 1999, 106:77-85

195. Kong SK, Halayko AJ, Stephens NL Increased myosin phosphorylation in sensitized canine tracheal smooth muscle $A m$ Physiol 1990, 259:L53-L56

196. Jiang H, Rao K, Halayko AJ, Liu X, Stephens NL Ragweed sensitization-induced increase of myosin light chain kinase content in canine airway smooth muscle $\mathrm{Am} J$ Respir Cell Mol Biol 1992, 7:567-573

197. Ammit AJ, Armour CL, Black JL Smooth-muscle myosin lightchain kinase content is increased in human sensitized airways Am J Respir Crit Care Med 2000, 161:257-263

198. Chiba $Y$, Sakai H, Misawa M Augmented acetylcholine-induced translocation of RhoA in bronchial smooth muscle from antigen-induced airway hyperresponsive rats $\mathrm{Br} J$ Pharmacol 2001, 133:886-890

199. McGraw DW, Chai SE, Hiller FC, Cornett LE Regulation of the beta 2-adrenergic receptor and its mRNA in the rat lung by dexamethasone Exp Lung Res 1995, 21:535-546

200. Jacoby DB, Yost BL, Kumaravel B, Chan-Li Y, Xiao HQ, Kawashima K, Fryer AD Glucocorticoid treatment increases inhibitory $m[2]$ muscarinic receptor expression and function in the airways $A m$ J Respir Cell Mol Biol 2001, 24:485-491

201. Schmidlin F, Scherrer D, Landry Y, Gies JP Glucocorticoids inhibit the bradykinin B2 receptor increase induced by interleukin-1beta in human bronchial smooth muscle cells Eur $J$ Pharmacol 1998, 354:R7-R8

202. Hardy E, Farahani M, Hall IP Regulation of histamine H1 receptor coupling by dexamethasone in human cultured airway smooth muscle Br J Pharmacol 1996, 118:1079-1084

203. Peters SP, Fish JE Prior use of long-acting beta-agonists: friend or foe in the emergency department? Am J Med 1999, 107:283-285

204. Cheung D, Timmers MC, Zwinderman AH, Bel EH, Dijkman JH, Sterk PJ Long-term effects of a long-acting beta 2-adrenoceptor agonist, salmeterol, on airway hyperresponsiveness in patients with mild asthma [see comments] N Engl J Med 1992, 327:1198-1203

205. Bhagat R, Kalra S, Swystun VA, Cockcroft DW Rapid onset of tolerance to the bronchoprotective effect of salmeterol Chest 1995, 108:1235-1239

206. Abisheganaden J, Boushey HA Long-acting inhaled beta 2-agonists and the loss of "bronchoprotective" efficacy $A m \mathrm{~J} M e d$ 1998, 104:494-497

207. Lipworth B Tolerance with beta-agonists - a clinical problem? In Beta-2-agonists in Asthma Treatment (Edited by: Pauwels R, O'Byrne PM) New York: Marcel Decker, Inc 1997, 349-365

208. January B, Seibold A, Allal C, Whaley BS, Knoll BJ, Moore RH Dickey BF, Barber R, Clark RB Salmeterol-induced desensitization, internalization and phosphorylation of the human beta2 adrenoceptor $\mathrm{Br} J$ Pharmacol 1998, 123:701-711
209. Clark RB, Allal C, Friedman J, Johnson M, Barber R Stable activation and desensitization of beta 2-adrenergic receptor stimulation of adenylyl cyclase by salmeterol: evidence for quasiirreversible binding to an exosite Mol Pharmacol 1996, 49:182189

210. Korosec M, Novak RD, Myers E, Skowronski M, McFadden ER Jr Salmeterol does not compromise the bronchodilator response to albuterol during acute episodes of asthma $\mathrm{Am} \mathrm{J}$ Med 1999, 107:209-213

211. Pierce KL, Luttrell LM, Lefkowitz RJ New mechanisms in heptahelical receptor signaling to mitogen activated protein kinase cascades Oncogene 2001, 20:1532-1539

212. Gutkind JS The pathways connecting G-protein coupled receptors to the nucleus through divergent mitogen-activated protein kinase cascades. J Biol Chem 1998, 273:1839-1842

213. Yang CM, Yo YL, Hsieh JT, Ong R 5-Hydroxytryptamine receptor-mediated phosphoinositide hydrolysis in canine cultured tracheal smooth muscle cells $\mathrm{Br} J$ Pharmacol 1994, 111:777786

214. Zacour ME, Martin JG Enhanced growth response of airway smooth muscle in inbred rats with airway hyperresponsiveness Am J Respir Cell Mol Biol 1996, 15:590599

215. Tolloczko B, Jia YL, Martin JG Serotonin-evoked calcium transients in airway smooth muscle cells $A m$ J Physiol 1995, 269:L234-L240

216. Abebe W, Mustafa SJ A1 adenosine receptor-mediated Ins $(1,4,5) \mathrm{P} 3$ generation in allergic rabbit airway smooth muscle Am J Physiol 1998, 275:L990-L997

217. Nyce JW, Metzger WJ DNA antisense therapy for asthma in an animal model Nature 1997, 385:721-725

218. Michoud MC, Tolloczko B, Martin JG Effects of purine nucleotides and nucleoside on cytosolic calcium levels in rat tracheal smooth muscle cells Am J Respir Cell Mol Biol 1997, 16:199205

219. Michoud MC, Tao FC, Pradhan AA, Martin JG Mechanisms of the potentiation by adenosine of adenosine triphosphate-induced calcium release in tracheal smooth-muscle cells $A m J$ Respir Cell Mol Biol 1999, 21:30-36

220. KneussI MP, Richardson JB Alpha-adrenergic receptors in human and canine tracheal and bronchial smooth muscle $J$ Appl Physiol 1978, 45:307-311

221. Noveral JP, Grunstein MM Adrenergic receptor-mediated regulation of cultures rabbit airway smooth muscle cell regulation Am J Physiol 1994, 267:L291-L299

222. Barnes PJ, Basbaum CB Mapping of adrenergic receptors in the trachea by autoradiography Exp Lung Res 1983, 5:183-192

223. Barnes PJ, Basbaum CB, Nadel JA Autoradiographic localization of autonomic receptors in airway smooth muscle. Marked differences between large and small airways $A m$ Rev Respir Dis 1983, 127:758-762

224. Zaagsma J, van der Heijden PJ, van der Schaar MW, Bank CM Differentiation of functional adrenoceptors in human and guinea pig airways Eur J Respir Dis Suppl 1984, 135:16-33

225. Hall IP, Widdop S, Townsend P, Daykin K Control of cyclic AMP levels in primary cultures of human tracheal smooth muscle cells $\mathrm{Br} J$ Pharmacol 1992, 107:422-428

226. Tomasic M, Boyle JP, Worley JF 3rd, Kotlikoff MI Contractile agonists activate voltage-dependent calcium channels in airway smooth muscle cells Am J Physiol 1992, 263:C106-C113

227. Farmer SG, Ensor JE, Burch RM Evidence that cultured airway smooth muscle cells contain bradykinin B2 and B3 receptors Am J Respir Cell Mol Biol 1991, 4:273-277

228. Mak JC, Barnes PJ Autoradiographic visualization of bradykinin receptors in human and guinea pig lung Eur J Pharmaco/ 1991, 194:37-43

229. Marsh KA, Hill SJ Bradykinin B2 receptor-mediated phosphoinositide hydrolysis in bovine cultured tracheal smooth muscle cells $B r J$ Pharmacol 1992, 107:443-447

230. Pyne S, Pyne NJ Bradykinin stimulates phospholipase $D$ in primary cultures of guinea-pig tracheal smooth muscle Biochem Pharmacol 1993, 45:593-603

231. Pyne S, Pyne NJ Bradykinin-stimulated phosphatidate and 1,2diacylglycerol accumulation in guinea-pig airway smooth muscle: evidence for regulation 'down-stream' of phospholipases Cell Signal 1994, 6:269-277 
232. Sarau HM Identification, molecular cloning, expression, and characterization of a cysteinyl leukotriene receptor $\mathrm{Mol}$ Pharmacol 1999, 56:657-663

233. Lynch KR Characterization of the human cysteinyl leukotriene CysLT1 receptor Nature 1999, 399:789-793

234. Panettieri RA, Tan EM, Ciocca V, Luttmann MA, Leonard TB, Hay DW Effects of LTD4 on human airway smooth muscle cell proliferation, matrix expression, and contraction in vitro: differential sensitivity to cysteinyl leukotriene receptor antagonists $\mathrm{Am}$ J Respir Cell Mol Biol 1998, 19:453-461

235. Figueroa DJ, Breyer RM, Defoe SK, Kargman S, Daugherty BL, Waldburger K, Liu O, Clements M, Zeng Z, O'Neill GP, Jones TR, Lynch KR, Austin CP, Evans JF Expression of the cysteinyl leukotriene 1 receptor in normal human lung and peripheral blood leukocytes $A m$ J Respir Crit Care Med 2001, 163:226233

236. Jonsson EW Functional characterisation of receptors for cysteinyl leukotrienes in smooth muscle Acta Physiol Scand Supp/ 1998, 641:1-55

237. Hay DW, Douglas SA, Ao Z, Moesker RM, Self GJ, Rigby PJ, Luttmann MA, Goldie RG Differential modulation of endothelin ligand-induced contraction in isolated tracheae from endothelin B (ET(B)) receptor knockout mice $\mathrm{Br} J$ Pharmacol 2001, 132:1905-1915

238. Kizawa Y, Ohuchi N, Saito K, Kusama T, Murakami H Effects of endothelin-1 and nitric oxide on proliferation of cultured guinea pig bronchial smooth muscle cells Comp Biochem Physiol C Toxicol Pharmacol 2001, 128:495-501

239. D'Agostino B, Gallelli L, Falciani M, Di Pierro P, Rossi F, Filippelli A Endothelin-1 induced bronchial hyperresponsiveness in the rabbit: an ET(A) receptor-mediated phenomenon Naunyn Schmiedebergs Arch Pharmacol 1999, 360:665-669

240. Hay DW, Luttmann MA, Muccitelli RM, Goldie RG Endothelin receptors and calcium translocation pathways in human airways Naunyn Schmiedebergs Arch Pharmacol 1999, 359:404-410

241. Takahashi T, Barnes PJ, Kawikova I, Yacoub MH, Warner TD, Belvisi MG Contraction of human airway smooth muscle by endothelin-1 and IRL 1620: effect of bosentan Eur J Pharmacol 1997, 324:219-222

242. Goldie RG, Henry PJ, Knott PG, Self GJ, Luttmann MA, Hay DW Endothelin-1 receptor density, distribution, and function in human isolated asthmatic airways $A m J$ Respir Crit Care Med 1995, 152:1653-1658

243. Cerutis DR, Nogami M, Anderson JL, Churchill JD, Romberger DJ, Rennard SI, Toews ML Lysophosphatidic acid and EGF stimulate mitogenesis in human airway smooth muscle cells. Am J Physiol 1997, 273:L10-L15

244. Nogami M, Whittle SM, Romberger DJ, Rennard SI, Toews M Lysophosphatidic acid regulation of cyclic AMP accumulation in cultured human airway smooth muscle cells Mol Pharmaco 1995, 48:766-773

245. Toews ML, Ustinova EE, Schultz HD Lysophosphatidic acid enhances contractility of isolated airway smooth muscle $J \mathrm{App} /$ Physiol 1997, 83:1216-1222

246. Fortner CN, Breyer RM, Paul RJ EP2 receptors mediate airway relaxation to substance $\mathbf{P}, \mathbf{A T P}$, and PGE2 Am J Physiol Lung Cell Mol Physiol 2001, 281:L469-L474

247. Sheller JR, Mitchell D, Meyrick B, Oates J, Breyer R EP[2] receptor mediates bronchodilation by PGE[2] in mice J App/ Physiol 2000, 88:2214-2218

248. Grandordy BM, Barnes PJ Airway smooth muscle and disease workshop: phosphoinositide turnover Am Rev Respir Dis 1987, 136:S17-S20

249. Daykin K, Widdop S, Hall IP Control of histamine induced inositol phospholipid hydrolysis in cultured human tracheal smooth muscle cells Eur J Pharmacol 1993, 246:135-140

250. Pascual RM, Billington CK, Hall IP, Panettieri RA, Fish JE, Peters $\mathrm{SP}$, Penn RB Comparison of chronic cytokine versus PGE2 pretreatment effects on G protein-coupled receptor (GPCR) signaling in human airway smooth muscle (HASM) [abstract]. Am J Respir Crit Care Med 2000, 161:A696

251. Mak JC, Barnes PJ Autoradiographic visualization of muscarinic receptor subtypes in human and guinea pig lung $A m \operatorname{Rev}$ Respir Dis 1990, 141:1559-1568
252. Mak JC, Baraniuk JN, Barnes PJ Localization of muscarinic receptor subtype mRNAs in human lung $\mathrm{Am} J$ Respir Cell Mol Biol 1992, 7:344-348

253. Roffel AF, Elzinga CR, Zaagsma J Muscarinic M3 receptors mediate contraction of human central and peripheral airway smooth muscle Pulm Pharmacol 1990, 3:47-51

254. Roffel AF, Meurs H, Elzinga CR, Zaagsma J Characterization of the muscarinic receptor subtype involved in phosphoinositide metabolism in bovine tracheal smooth muscle $\mathrm{Br} J$ Pharmacol 1990, 99:293-296

255. Yang CM, Chou SP, Wang YY, Hsieh JT, Ong R Muscarinic regulation of cytosolic free calcium in canine tracheal smooth muscle cells: Ca2+ requirement for phospholipase C activation $\mathrm{Br} J$ Pharmacol 1993, 110:1239-1247

256. Watson N, Barnes PJ, Maclagan J Actions of methoctramine, a muscarinic $M 2$ receptor antagonist, on muscarinic and nicotinic cholinoceptors in guinea-pig airways in vivo and in vitro $\mathrm{Br} J$ Pharmacol 1992, 105:107-112

257. Mapp CE, Miotto D, Braccioni F, Saetta M, Turato G, Maestrelli $P$, Krause JE, Karpitskiy V, Boyd N, Geppetti P, Fabbri LM The distribution of neurokinin-1 and neurokinin-2 receptors in human central airways Am J Respir Crit Care Med 2000, 161:207-215

258. Mak JC, Astolfi M, Zhang XL, Evangelista S, Manzini S, Barnes P Autoradiographic mapping of pulmonary NK1 and NK2 tachykinin receptors and changes after repeated antigen challenge in guinea pigs Peptides 1996, 17:1389-1395

259. Noveral JP, Grunstein MM Tachykinin regulation of airway smooth muscle cell proliferation Am J Physiol 1995, 269:L339 L343

260. Grandordy BM, Frossard N, Rhoden KJ, Barnes PJ Tachykinin-induced phosphoinositide breakdown in airway smooth muscle and epithelium: relationship to contraction $\mathrm{Mol}$ Pharmacol 1988, 33:515-519

261. Berger P, Perng DW, Thabrew H, Compton SJ, Cairns JA, McEuen AR, Marthan R, Tunon De Lara JM, Walls AF Tryptase and agonists of PAR-2 induce the proliferation of human airway smooth muscle cells J Appl Physiol 2001, 91:1372-1379

262. Berger $P$, Tunon-De-Lara JM, Savineau JP, Marthan R Selected contribution: tryptase-induced PAR-2-mediated $\mathrm{Ca}(2+)$ signaling in human airway smooth muscle cells J App/ Physiol 2001 , 91:995-1003

263. Kawikova I, Barnes PJ, Takahashi T, Tadjkarimi S, Yacoub MH, Belvisi MG 8-Epi-PGF2 alpha, a novel noncyclooxygenase-derived prostaglandin, constricts airways in vitro $A m J$ Respir Crit Care Med 1996, 153:590-596

264. Noveral JP, Grunstein MM Role and mechanism of thromboxane-induced proliferation of cultured airway smooth muscle cells Am J Physiol 1992, 263:L555-L561

265. Tilley SL, Coffman TM, Koller BH Mixed messages: modulation of inflammation and immune responses by prostaglandins and thromboxanes $J$ Clin Invest 2001, 108:15-23

266. Armour CL, Johnson PR, Alfredson ML, Black JL Characterization of contractile prostanoid receptors on human airway smooth muscle Eur J Pharmacol 1989, 165:215-222

267. Carstairs JR, Barnes PJ Visualization of vasoactive intestinal peptide receptors in human and guinea pig lung $J$ Pharmacol Exp Ther 1986, 239:249-255

268. Lazarus SC, Basbaum CB, Barnes PJ, Gold WM cAMP immunocytochemistry provides evidence for functional VIP receptors in trachea $A m$ J Physiol 1986, 251:C115-C119

269. Winder SJ, Walsh MP Smooth muscle calponin. Inhibition of actomyosin MgATPase and regulation by phosphorylation $\mathrm{J}$ Biol Chem 1990, 265:10148-10155

270. Chikumi H, Vazquez-Prado J, Servitja JM, Miyazaki H, Gutkind JS Potent Activation of RhoA by Galpha $q$ and $\mathrm{Gq}$-coupled Receptors J Bio/ Chem 2002, 277:27130-27134

271. Kim MK, Caspi RR, Nussenblatt RB, Kuwabara T, Palestine AG Intraocular trafficking of lymphocytes in locally induced experimental autoimmune uveoretinitis (EAU) Cell Immunol 1988 112:430-436

272. Togashi H, Emala CW, Hall IP, Hirshman CA Carbachol-induced actin reorganization involves $\mathrm{Gi}$ activation of $\mathrm{Rho}$ in human airway smooth muscle cells Am J Physiol 1998, 274:L803-L809

273. Croxton TL, Lande B, Hirshman CA Role of $G$ proteins in agonistinduced $\mathrm{Ca2}+$ sensitization of tracheal smooth muscle $\mathrm{Am} J$ Physiol 1998, 275:L748-L755 
274. Pang L, Knox AJ Regulation of TNF-alpha-induced eotaxin release from cultured human airway smooth muscle cells by beta2-agonists and corticosteroids FASEB J 2001, 15:261 269

275. Lazzeri N, Belvisi MG, Patel HJ, Yacoub MH, Fan Chung K, Mitchell JA Effects of prostaglandin E2 and cAMP elevating drugs on GM-CSF release by cultured human airway smooth muscle cells. Relevance to asthma therapy Am J Respir Cell Mol Biol 2001, 24:44-48

276. Lazzeri N, Belvisi MG, Patel HJ, Chung KF, Yacoub MH, Mitchell JA RANTES release by human airway smooth muscle: effects of prostaglandin E[2] and fenoterol Eur J Pharmacol 2001, 433:231-235

277. Gerthoffer WT Agonist synergism in airway smooth muscle contraction J Pharmacol Exp Ther 1996, 278:800-807

278. Ediger TL, Toews ML Synergistic stimulation of airway smooth muscle cell mitogenesis J Pharmacol Exp Ther 2000, 294:10761082

279. Togashi $H$, Hirshman CA, Emala CW Qualitative immunoblot analysis of PKC isoforms expressed in airway smooth muscle Am J Physiol 1997, 272:L603-L607

280. Hirshman CA, Togashi H, Shao D, Emala CW Galphai-2 is required for carbachol-induced stress fiber formation in human airway smooth muscle cells Am J Physiol 1998, 275:L911-L916

281. Fryer $A D$, Jacoby $D B$ Muscarinic receptors and control of airway smooth muscle Am J Respir Crit Care Med 1998, 158:S154$\mathrm{S} 160$ 